\title{
The catastrophic final flooding of Doggerland by the Storegga Slide tsunami
}

\author{
Bernhard Weninger' ${ }^{1}$ Rick Schulting ${ }^{2}$, Marcel Bradtmöller3, Lee Clare', Mark Collard4, \\ Kevan Edinborough4, Johanna Hilpert ${ }^{1}$, Olaf Jöris 5 , Marcel Niekus ${ }^{6}$, Eelco J. Rohling7, \\ Bernd Wagner 8 \\ 1 Universität zu Köln, Institut für Ur- und Frühgeschichte, Radiocarbon Laboratory, Köln, D, \\ b.weninger@uni-koeln.de; 2 School of Archaeology, University of Oxford, Oxford, UK; \\ 3 Neanderthal Museum, Mettmann, D; 4 Laboratory of Human Evolutionary Studies, Dpt. of Archaeology, \\ Simon Fraser University, Burnaby, CDN; 5 Römisch Germanisches Zentralmuseum Mainz, D; \\ 6 Groningen Institute of Archaeology, Groningen, NL; 7 School of Ocean and Earth Science, National \\ Oceanography Centre, Southampton, UK; 8 Universität zu Köln, Institut für Geologie und Mineralogie, Köln, D
}

\begin{abstract}
Around 8200 calBP, large parts of the now submerged North Sea continental shelf ('Doggerland') were catastrophically flooded by the Storegga Slide tsunami, one of the largest tsunamis known for the Holocene, which was generated on the Norwegian coastal margin by a submarine landslide. In the present paper, we derive a precise calendric date for the Storegga Slide tsunami, use this date for reconstruction of contemporary coastlines in the North Sea in relation to rapidly rising sea-levels, and discuss the potential effects of the tsunami on the contemporaneous Mesolithic population. One main result of this study is an unexpectedly high tsunami impact assigned to the western regions of Jutland.
\end{abstract}

IZVLEČEK - Okoli 8200 calBP je velik del danes potopljenega severnomorskega kontinentalnega pasu (Doggerland) $v$ katastrofalni poplavi prekril cunami. To je eden največjih holocenskih cunamijev, ki ga je povzročil podmorski plaz na norveški obali (Storegga Slide). V članku predstavljamo natančne datume za cunami Storegga Slide in jih uporabimo pri rekonstrukciji takratnih obal Severnega morja, $v$ času naglega dviganja morske gladine. Dotaknemo se tudi možnih posledic cunamija za mezolitske populacije. Glavni rezultat študije je nepričakovano močan vpliv cunamija na zahodni del Jutlanda.

KEY WORDS - Mesolithic; Doggerland; Storegga Slide tsunami

\section{Introduction}

The hypothesis that a major tsunami was generated by an underwater slide off the west coast of Norway was first proposed by Svendsen (1985) and further elaborated in a large number of studies (e.g. Bondevik 2003; Bondevik et al. 1997; 2003; 2005; 2006; Dawson et al. 1988; 1990; 1993; Grauert et al. 2001; Haflidason et al. 2005; Long et al. 1989; Smith et al. 1985; 2004). As a result of detailed fieldwork (e.g. Bondevik et al. 1997; 2003; 2005; Smith et al. 2004), followed by comprehensive modelling studies (Har- bitz 1992; Bondevik et al. 2005), a comparatively large number of deposits on the coasts of Norway and eastern Scotland can now be safely attributed to the Second Storegga Slide tsunami. The generation of the tsunami apparently involved some 2400$3200 \mathrm{~km}^{3}$ of material that spread across the North Atlantic sea floor, altogether covering an area of around $95000 \mathrm{~km}^{2}$ (Haflidason et al. 2005) - that is about the size of Scotland. Bryn et al. (2005) suggest the cause of the Storegga slide was a strong 
earthquake in the North Atlantic, but further investigations are necessary to substantiate this hypothesis. Due to the large slide/slump volume and extensive reworking, the direct dating of the slide sediments is no easy matter. Comprehensive analysis of a long (more than $50{ }^{14} \mathrm{C}$-ages) series of AMS-radiocarbon ages for stratified basal post-slide sediments, processed on purposely chosen monospecific planctonic foraminifera (Neogloboquadrina pachyderma and Globigerina bulloides) to reduce the risk of reworking, give an (averaged) direct date for the main slide of $7250 \pm 250{ }^{14} \mathrm{C}$ yrs BP (Haflidason et al. 2005).

Traces of the corresponding Second Storegga Slide tsunami have been identified in many regions of the North Atlantic, with the best-studied locations on the coast of Norway and eastern Scotland. On the Norwegian coast, at locations directly opposite to the sub-marine landslide region, the tsunami had a maximum runup of $10-12 \mathrm{~m}$. Further north, a runup of $6-7 \mathrm{~m}$ is reconstructed. On the eastern coast of Scotland typical runup heights exceed 3-5m (Smith et al. 2004). Storegga deposits are also known from the Faroes (Grauert et al. 2001) and the Shetland Islands, where runup exceeds $20 \mathrm{~m}$ (Bondevik et al. 2005). Recent studies show that the tsunami probably even reached the east coast of Greenland (Wagner et al. 2007). This would agree with modelling studies (Bondevik et al. 2005), according to which the wave front would have crossed the North Atlantic within 3 hours, with maximal elevation on the open ocean of $3 \mathrm{~m}$. The size of these waves, and their spread over such a large area, indicate that most of the volume of the slide was involved in the generation of the tsunami (Bondevik et al. 2005). On the Norwegian coast, the arrival of the first wave would have been associated with a major water withdrawal, corresponding to a predicted initial sea-level drop of $20 \mathrm{~m}$. The model also predicts that multiple waves should occur. This is confirmed for deposits probably laid down by the Storegga slide tsunami on the east coast of Greenland, where the grain-size composition, biogeochemical and macrofossil data indicate that the Loon Lake basin was inundated by at least four waves (Wagner et al. 2007). The effects of the tsunami on other North Sea coasts - and notably on Mesolithic Doggerland (Coles 1998) - have not yet been modelled. As a starting point for our studies towards the potential effects of the Storegga Slide tsunami in the southern North Sea, we assume that runup in this region is likely to have been around 3m (pers. comm. Bondevik 2007).

\section{Tsunami deposits}

The accurate dating of the Storegga Slide Tsunami represents a major challenge to established radiocarbon methodology. As already recognised by Bondevik et al. (2006), the accurate radiocarbon dating of palaeotsunamis is problematic for three reasons: (1) erosion of the underlying strata, (2) redeposition of organic material within the tsunami deposit, and (3) redeposition of organic matter following the tsunami event. Due to the importance of these issues for radiocarbon dating, we begin with a brief description of the tsunami deposits under study on the coasts of Norway and Great Britain.

\section{Norway}

In Norway, the Storegga Slide tsunami deposits are typically recognised as a distinct layer of sand in peat outcrops, with an underlying and often sharply eroded surface (Bondevik et al. 1997; 2003). Similar observations have been made all along the eastern coast of Scotland, where the inferred tsunami deposits are readily recognised by a recurring sand layer within raised estuarine sediments that pass into peat in a landward direction (Dawson et al. 1993). This sand layer, both in Norway and Scotland (see below), contains a variety of chaotically redeposited organic materials, including twigs and bark. These are the samples, typically described as deriving from 'within the tsunami layer', that were carefully selected during field-work. When short-lived (annual growth) dating material (e.g. twigs, bark) is available, this is the preferred material submitted for radiocarbon dating, in contrast to peat samples, which are expected to have an in-built 'older' age due to peat growth processes.

Along the Norwegian coast, as observed at higher levels, the tsunami inundated a number of fresh-water bodies, again leaving behind a characteristic sand layer. These deposits contain redeposited lake mud, rip-up clasts, and churned up marine fossils. This sand layer has many of the characteristic properties known from modern tsunami deposits. In particular, the observations made for the Storegga Slide tsuna$\mathrm{mi}$ are consistent with the modern observation that tsunamis are commonly associated with at least two waves, with the second wave arriving within minutes, but even up to a few hours after the first, depending on distance to the source (Bondevik et al. 2005). Regarding the geological situation in Norway, the first wave typically appears to have eroded the peat surface, producing huge amounts of rip-up peat clasts, which were then chaotically redeposited along with 
other organic remains, during the backwash. The second wave then appears to have buried these materials in a layer of sand (Bondevik et al. 1997).

In order to accurately measure the runup heights for the Storegga tsunami, Bondevik et al. (2005) developed a novel method for runup reconstruction, which is applicable to the large number of tsunami deposits known from the Norwegian coast. The method is to map the precise heights of the tsunami deposits in a series of increasingly higher lake basins, until the maximum height is reached. By this method, it appears that the waves inundated the coastal lakes up to $10-12 \mathrm{~m}$ above contemporary sea-level, but failed to reach lakes at a height of $13 \mathrm{~m}$ (Bondevik et al. 2005). Similar to the Shetland islands, as described below, the reconstructed maximal runup depends strongly on the established local contemporary sea-level, but in this case that level is well constrained (to within $1 \mathrm{~m}$ ), due to previous studies of Glacial uplift for the Fennoscandian ice-shield.

According to Bondevik et al. (2003), the tsunami deposits in Norway were sampled for radiocarbon dating by the careful selection of short-lived plant macrofossils. Such samples are available both from peat outcrops, as well as lakes. From the peat deposits, the ages judged most reliable were obtained on seeds found immediately below the sand layer. Further sampling emphasis is on leaves and seeds from lake mud just above the tsunami deposit. In one case, a radiocarbon age was obtained on a stick immediately above the sand layer. Following critical sample selection, Bondevik et al. (1997) propose that the tsunami most likely dates to $c .7300{ }^{14} \mathrm{C}-\mathrm{BP}$. This age is supported by Bondevik et al. (2003), who give a calibrated age value of $c .8150$ calBP.

\section{Scotland}

Geological observations probably relating to the Storegga tsunami are also available for the east coast of Scotland, where a conspicuous sand layer is recognised at numerous localities (Dawson et al. 1988; 1993; Smith et al. 2004). According to Dawson et al. (1990), this sand layer was deposited by a major tsunami believed to have overwhelmed a Mesolithic occupation at Inverness, and it may also have flooded other Scottish archaeological sites, e.g. at Morton. Ballantyne (2004) urges interpretational caution, however, since localised storm events would have had equally catastrophic effects, particularly during a period of rapidly rising sea-levels. The sand layer is not found on the west coast of Scotland. This would be indicative of a tsunami coming from the east.

\section{Britain}

A useful review of all the currently known sites in the United Kingdom with evidence of the Storegga Slide tsunami is given by Smith et al. (2004). These authors demonstrate that the tsunami affected a much larger coastal area than previously described, with the total length of the inundated coastline reaching more than $600 \mathrm{~km}$ along eastern Scotland. In addition to giving information on the altitude, distribution, stratigraphical context, and microfossil characteristics of the deposits, it is shown by detailed particle size analysis that the majority of tsunami sand deposits have a marked fining-upwards characteristic. This is important, because it gives information pertaining to the dynamics of the wave at different heights. Since sedimentation is only possible when the suspended sand particles are released, the implication is that the tsunami runup is likely to have exceeded the measured maximal height of the sand layer by several metres (Smith et al. 2004, with references). This study is of further interest, since the authors invest some effort in discussing the taphonomic properties of the dated samples, in search of a useful dating strategy.

According to Smith et al. (2004), based on a total of 47 radiocarbon dates from the United Kingdom, the tsunami event took place sometime around 7100 ${ }^{14} \mathrm{C}$-BP (7900 calBP). This estimate seems about 200 years later than that from Norway (Bondevik et al. 1997; 2003), but this 'offset' likely results from the different dating approaches in the Norwegian and British studies.

In their ${ }^{14} \mathrm{C}$-analysis, which is of special interest to us for the purposes of comparison, Smith et al. (2004) describe and classify the UK ${ }^{14} \mathrm{C}$-dates according to whether the samples have a 'transgressive' or 'regressive' overlap with the tsunami sand layer. The idea is that it might be possible to produce a statistical 'sandwich' date for the tsunami, when large numbers of such paired dates are analysed. As mentioned by Smith et al. (2004), this approach could be problematic, since the derived dates from the contact zone might turn out too young, if there is a delay in peat growth on the sand layer, following the tsunami. To further analyse the UK dates, and notably to compare the results of applying different descriptive approaches to the tsunami deposits, we have adopted the database of Smith et al. (2004) essentially unchanged (Appendix, Tab. 8).

\section{England (Howick case study)}

Further south, deposits that have been attributed to the Storegga tsunami have been identified in the 
vicinity of the Mesolithic site at Howick, situated in Northumberland on the east coast of England (BOomer et al. 2007). For these deposits a set of ${ }^{14} \mathrm{C}$ ages is available (Tab. 1). It is important to note that these ${ }^{14} \mathrm{C}$-ages are not from the Mesolithic coastal clifftop site at Howick (Waddington 2007), but from a core, approximately 800cm long core (HEX02 11007) taken from riverine sediment in the immediate vicinity of the site (Boomer et al. 2007). The stratigraphic situation in core HEX02 11007 is highly complex. According to the detailed description by Boomer et al. (2007), core HEX02 11007 contains a $30 \mathrm{~cm}$ layer of coarse sands and sandstone pebbles, which is distinctly defined at a depth of around 750$705 \mathrm{~cm}$. Due to a lack of samples, no ${ }^{14} \mathrm{C}$-dates are available from this layer. Terrestrial samples from immediately below this layer have ages ranging between 8.2 and $10 \mathrm{ka}{ }^{14} \mathrm{C}-\mathrm{BP}$. They do not contribute to the present discussion. Hazelnut shells from the immediately overlying deposits have supplied a date of $7269 \pm 39{ }^{14} \mathrm{C}-\mathrm{BP}(0 \mathrm{xa}-11833)$ at a depth of $685-$ $684 \mathrm{~cm}$, and a statistically identical date of $7308 \pm 40$ ${ }^{14} \mathrm{C}-\mathrm{BP}(0 \mathrm{xA}-11858)$ at $683 \mathrm{~cm}$ depth. In the stratigraphy $53 \mathrm{~cm}$ higher, there follows a slightly younger date from a hazel twig (0xA-11860: $7160 \pm 40$ $\mathrm{BP})$, and further dates around $7 \mathrm{ka}{ }^{14} \mathrm{C}-\mathrm{BP}$ are obtained at depths up to $580 \mathrm{~cm}$. According to Boomer et al. (2007), the sand layer at $750-705 \mathrm{~cm}$ may be related to the Storegga tsunami. It appears as a distinct and 'chaotic' clastic unit, within an otherwise uniform and fine-grained riverine sediment. Although quite different from the tsunami deposits along the Scottish coast, the geological context of this layer is indicative of an extremely high-energy event.

Although we can follow the authors in relating this layer to the Storegga tsunami, we are not convinced of the proposed age of 8350 calBP for the event, which was derived by Bayesian linear regression analysis of the sample stratigraphy at heights above the sand layer. As an alternative approach, further described below in the context of a model we have developed for radiocarbon dating of chaotic tsunami deposits, we propose simply to take the two (statistically identical) dates closest to the clastic unit (Oxa11833 and $0 x A-11858$ ), calculate their weighted et al. 2007). average, and use the age value as a close terminus ante quem for the tsunami event.

This weighted average $\left(7308 \pm 28{ }^{14} \mathrm{C}-\mathrm{BP}: 8110 \pm\right.$ 50 calBP) corresponds closely to the date of 7300 ${ }^{14} \mathrm{C}-\mathrm{BP}$ (8150 calBP) proposed by Bondevik et al. (1997) and Bondevik et al. (2003), but disagrees significantly with the result of 8350 calBP obtained by Boomer et al. (2007). If the Boomer et al. (2007) estimate is correct, then the dating discrepancy poses the question of whether both studies are addressing the same event, and notably whether the event observed at Howick indeed represents the Storegga Slide tsunami. Boomer et al. (2007) mention that the clear identification of tsunami deposits at Howick requires further fieldwork, but do not comment on the issue of why there should be a large (200 yr) discrepancy between the ages of the Storegga Slide tsunami at Howick and on the Norwegian coast. In contrast, our simpler and more straightforward approach to dating the event in Howick would suggest that the deposits at Howick are of exactly the same age (within confidence limits) as the Storegga event deposits in Norway.

\section{Radiocarbon dating model for tsunami depo- sits}

The difficulties encountered when radiocarbon dating palaeotsunamis, when based on peat stratigraphies with intercalated tsunami deposits, can be seen as a chain of interrelated problems: (i) the tsunami wave(s) will have cut away an undefined amount of peat, such that (ii) the deposits remaining in-situ ('below the tsunami') after the waves have passed may be of any age, ranging from decades to hundreds of years older than the event of interest. Next, (iii) reworking the highly mobile deposits will cause the majority of samples found 'within the tsunami la-

\begin{tabular}{|l|c|c|c|c|c|}
\hline Lab Code & ${ }^{14} \mathbf{C}-$ Age [BP] & $\begin{array}{c}\boldsymbol{\delta}^{13} \mathbf{C} \\
\text { [\%० PDB] }\end{array}$ & Material & $\begin{array}{c}\text { Core Depth } \\
{[\mathbf{c m}]}\end{array}$ & $\begin{array}{c}\text { Calendric Age } \\
\text { [calBP] (68\%) }\end{array}$ \\
\hline Oxa-12952 & $6988 \pm 37$ & $-26,5$ & hazelnut shell & 580 & $7840 \pm 60$ \\
\hline Oxa-12953 & $7117 \pm 39$ & $-26,1$ & hazelnut shell & 580 & $7940 \pm 40$ \\
\hline OxA-12954 & $7075 \pm 37$ & $-30,7$ & sliver of wood bark & 583 & $7910 \pm 40$ \\
\hline OxA-11859 & $7174 \pm 35$ & $-26,4$ & carbonised wood & 627 & $7990 \pm 30$ \\
\hline OxA-11860 & $7160 \pm 40$ & $-27,3$ & hazel twig & 630 & $7980 \pm 30$ \\
\hline OxA-11858 & $7308 \pm 40$ & $-25,6$ & hazelnut shell & 683 & $8110 \pm 50$ \\
\hline OxA-11833 & $7269 \pm 39$ & $-24,9$ & hazelnut shell & $684-685$ & $8090 \pm 60$ \\
\hline Tsunami & - & - & $\begin{array}{c}\text { poorly sorted, } \\
\text { coarse clastic unit }\end{array}$ & $705-750$ & - \\
\hline
\end{tabular}

Tab. 1. Selected Radiocarbon Ages from Howick, Core HEXO2 11007 (Boomer 
yer' to have dates totally unrelated to the tsunami event, and (iv) due to the good conservation of organic substances in peat deposits, the 'short-lived' samples (e.g. leaves, seed) found 'within the tsunami layer' may originate from older layers, Finally, (v) due to the differential sedimentation of the reworked materials (peat, sand, rocks, twigs, leaves, seeds) many of the plant materials taken from layers 'above the tsunami' may not be younger, as perhaps expected, but rather again represent older samples, since these (twigs, leaves, seeds) would have the longest floatation times. That these expected effects may indeed be effective for the deposits under study in Norway, England and Greenland is shown in Figure 1.

We omit discussion of the four irrelevant samples that are catalogued as deriving from 'below the tsunami' (Fig. 1). The following group of samples designated as taken from 'directly below' the tsunami show the expected wide spread of ages, with an overall range of $9300-8180$ calBP. Interestingly, the samples from 'within the tsunami sand' show the same overall spread in age, but this group ends with an enhanced cluster of dates, centred on the time-window 8200-8000 calBP, which give the appearance of a sharply defined age cut-off. We have shaded the corresponding region range (8000-8200 calBP) in Figure 1, and have also extracted the cor-

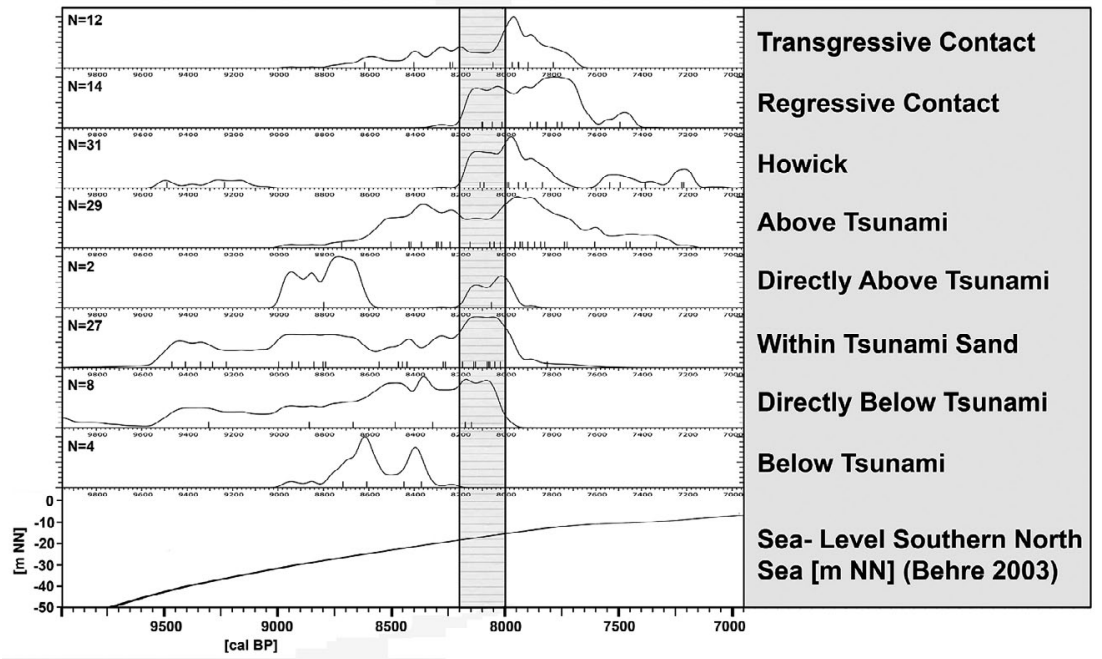

Fig. 1. Calibrated radiocarbon ages for tsunami deposits from Norway, East Greenland, and Britain, arranged according to descriptive taphonomic terms (Below Tsunami, Directly Below Tsunami, Within Tsunami Sand, Directly Above Tsunami, Above Tsunami, Transgressive Contact, Regressive Contact). Due to chaotic reworking of tsunami deposits temporal relations such as 'older' or 'younger' do not correctly describe the sample sequence (cf. text). The applied descriptive terms allow for this situation and support visual identification of meaningful tsunami samples (cf. text). We conclude the Storegga Slide tsunami dates between 8200 and 8000 calBP (vertical shading, cf. Fig. 2). responding time-windows for all groups, for further analysis. As it turns out, all samples belonging to this time-window and selected from the group 'within the tsunami sand' were processed on short-lived samples (moss, twigs, bark cf. Tab. 2).

The next 'younger' group (Fig. 1) taken from ' $\boldsymbol{d i}$ rectly above the tsunami' contains only two samples, one of which is a churned up and redeposited shell from Loon Lake (East Greenland), dating to $8800 \pm 120$ calBP (KIA-27661: $7925 \pm 45$ 14C-BP). The second date in this group is also older than expected. The multi-group sequence continues with an exceptionally large ('default') group of widely spreading dates on samples taken from 'above the tsunami'. We note that this group contains just as many dates 'younger' than the tsunami, as dates that are clearly 'older'. The following set of dates from Howick Core HEX02 11007 (Fig. 1) contains the two short-lived dates on hazelnut, already discussed above (0xA-11833: $7269 \pm$ 39; 0xA-11858: $7308 \pm$ $\left.40{ }^{14} \mathrm{C}-\mathrm{BP}\right)$. Both dates, and especially their weighted average of $7308 \pm 28{ }^{14} \mathrm{C}-\mathrm{BP}(8110 \pm 50 \mathrm{calBP})$, have a central position within the shaded time-window of the Storegga Slide tsunami. As discussed above, these samples were taken from immediately above the possible tsunami sands. The position of these two samwithin the overall tsunami group sequence now simultaneously confirms the identification of these sands as laid down by the Storegga tsunami, and refutes the date of 8350 calBP derived from Bayesian stratigraphic analysis (Boomer et al. 2007). Finally, as shown in Figure 1, the classification of ${ }^{14} \mathrm{C}$ - dates from eastern Scotland (Smith et al. 2004) according to the descriptive stratigraphic terms 'Regressive Contact' and 'Transgressive Contact' with the tsunami sand layer does not allow the required clear distinction between samples contemporaneous with the tsunami, and other (older or younger) samples, as was already recognised by the authors (Smith et al. 2004).

At this point of the discussion, we have two weighted ${ }^{14} \mathrm{C}$-age averages at our dispo- 
sal, both directly dating the tsunami event, that is (i) $7298 \pm 26{ }^{14} \mathrm{C}-\mathrm{BP}$ for $\mathrm{N}=10$ selected short-lived samples from $\mathrm{N}=5$ different sites in Norway (Tab. 2), and (ii) $7308 \pm 28{ }^{14} \mathrm{C}-\mathrm{BP}$ for two selected samples from Howick in England (Tab. 3).

There is a strong agreement between these two values and calculation of the weighted average for the two combined ages $\left(7298 \pm 26{ }^{14} \mathrm{C}\right.$-BP and $7308 \pm 28$ ${ }_{14} \mathrm{C}$-BP) finally gives $7308 \pm 19$ 14C-BP. A statistical Chi-Square test gives $95 \%$ probability that the observed spread in the overall underlying data (total $\mathrm{N}=12$ ages on short-lived samples from $\mathrm{N}=6$ different sites in 2 countries; $c f$ Tab. 3) can be explained by random effects in the ${ }^{14} \mathrm{C}$-measurement procedures.

To allow for possible differences in interlaboratory calibration, as well as for advisable caution in subsequent interpretation we raise the calculated error from $\pm 19{ }^{14} \mathrm{C}$-BP to $\pm 30{ }^{14} \mathrm{C}$-BP. This measure is neither necessary nor indicated by the given data; we simply wish to remain on the safe side of the radiocarbon-based chronological world of chance.

As a final measure, again only taken for convenience, in all following discussions we base our argumentation on the rounded value $7300 \pm 30{ }^{14} \mathrm{C}-\mathrm{BP}(8110 \pm$ 100 calBP, $p=95 \%$ ).

In conclusion, although we have not been able to demonstrate the existence of a reliable (single sample) dating method for Storegga Slide deposits, the 'best' sampling (and classification) method appears to be the careful selection of short-lived macro-samples from within the tsunami sands. By comparing the spread of calibrated median values for sample groups classified by different field criteria (Fig. 1), we can show that a well-defined 'cut-off' age exists, for shortlived samples taken from the tsunami sands. These results corroborate and highlight the sampling strategy of Bondevik et al. (2006), which advocates the AMS radiocarbon dating of green (chlorophyll-rich) moss stems.

\section{Palaeogeographic boundary conditions}

Due to rising sea-levels in the $9^{\text {th }}$ millennium calBP, the exact timing of the Storegga Slide tsunami relative to contemporaneous sea-levels in the North Sea is of major importance for the reconstruction of the tsunami-'s environmental impact. At this time the North Sea region was experiencing a phase of most rapid early Holocene sea-level change (Lambeck 1995; Shennan et al. 2000; Behre 2003), in combination with equally significant glacio- and hydro-isostatic land-level changes, e.g. tilting of Scotland and Norway (Lambeck 1995; Dawson and Smith 1997; Gyllencreutz 2005b). To further complicate matters, due to rapidly rising sea-levels during the $9^{\text {th }}$ millennium, more and more sections of Doggerland - a now submerged land-area situated between Britain and the continent (Coles 1998) - were becoming submerged. Allowance also has to be made for the tidal regime at the time.

To facilitate study of the environmental impact of the Storegga Slide tsunami in the southern parts of Doggerland (where we expect the highest density of Mesolithic occupation, see below), we can now rely on a highly accurate date for the tsunami event at our disposal: $7300 \pm 30{ }^{14} \mathrm{C}$-BP (95\%-confidence), or $8100 \pm 100$ calBP (95\%-confidence). The importance of using an appropriate regional sea-level value in any investigation of the impact of the Storegga slide tsunami is exemplified by data from the Shetland Islands. There, the tsunami appears to have invaded

\begin{tabular}{|l|c|c|c|c|c|c|c|c|l|}
\hline Lab Code & ${ }^{14}$ C-Age & $\begin{array}{c}{ }^{13} \text { C- } \\
\text { PDB }\end{array}$ & Material & Country & Site & Position & Latitude & Long. & Reference \\
\hline Tua-1350 & $7315 \pm 70$ & $-22,9$ & Moss & Norway & Audalsvatnet & within Tsunami & 63,8314 & 9,8289 & Bondevik et al. 1997 \\
\hline Tua-834 & $6970 \pm 175$ & -26 & Twig & Norway & Gorrtjonna I & within Tsunami & 63,8264 & 9,8308 & Bondevik et al. 1997 \\
\hline Tua-1269 & $7445 \pm 65$ & $-29,5$ & Twig & Norway & Gorrtjonna I & within Tsunami & 63,8264 & 9,8308 & Bondevik et al. 1997 \\
\hline Tua-1122 & $7175 \pm 75$ & $-30,7$ & Twig & Norway & Klingrevatnet & within Tsunami & 62,4424 & 6,2324 & Bondevik et al. 1997 \\
\hline Tua-831 & $7240 \pm 70$ & $-27,7$ & Twig & Norway & Kvennavatnet & within Tsunami & 63,8347 & 9,8225 & Bondevik et al. 1997 \\
\hline Tua-984 & $7200 \pm 80$ & $-26,1$ & Twig & Norway & Kvennavatnet & within Tsunami & 63,8347 & 9,8225 & Bondevik et al. 1997 \\
\hline T-10597 & $7230 \pm 105$ & $-26,1$ & Twig & Norway & Ratvikvatnet & within Tsunami & 62,4619 & 6,2242 & Bondevik et al. 1997 \\
\hline Tua-861 & $7250 \pm 75$ & $-26,1$ & Bark & Norway & Skolemyra & within Tsunami & 62,3331 & 5,6486 & Bondevik et al. 1997 \\
\hline Tua-524 & $7365 \pm 90$ & $-26,1$ & Twig & Norway & Skolemyra & within Tsunami & 62,3331 & 5,6486 & Bondevik et al. 1997 \\
\hline Tua-860 & $7435 \pm 75$ & $-26,1$ & Bark & Norway & Skolemyra & within Tsunami & 62,3331 & 5,6486 & Bondevik et al. 1997 \\
\hline
\end{tabular}

Tab. 2. Subgroup of 14C-Ages for Samples taken from 'Within the Tsunami Deposit', with ages 80008200 calBP (cf. Fig. 1). Weighted Average: $7298 \pm 2614 \mathrm{C}-\mathrm{BP}$ (8110 \pm 50 calBP). 


\begin{tabular}{|l|c|c|c|c|c|c|c|c|l|}
\hline Lab Code & ${ }^{14}$ C-Age & $\begin{array}{c}{ }^{13} \text { C- } \\
\text { PDB }\end{array}$ & Material & Country & Site & Position & Latitude & Longitude & Reference \\
\hline Oxa-11833 & $7269 \pm 39$ & $-24,9$ & hazelnut & England & Howick & directly above & 55,4403 & $-1,5917$ & Boomer et al. 2007 \\
\hline Oxa-11858 & $7308 \pm 40$ & $-25,6$ & hazelnut & England & Howick & directly above & 55,4403 & $-1,5917$ & Boomer et al. 2007 \\
\hline
\end{tabular}

Tab. 3. Subgroup of ${ }^{14}$ C-Ages on Samples taken from 'Directly Above the Tsunami Deposit', from Howick (Great Britain) (cf. Fig. 1). Weighted Average: $7308 \pm 28{ }^{14} \mathrm{C}-B P(8110 \pm 50 \mathrm{calBP})$.

coastal lakes and have run up peaty hillsides to a maximum height of $9.2 \mathrm{~m}$ above the present high tide level (Bondevik et al. 2005). However, around $7300{ }^{14} \mathrm{C}-\mathrm{BP}$, sea levels around the Shetland Islands and the Faroes stood at $10-15 \mathrm{~m}$ below the present level (Lambeck 1995), so that the reconstructed runup height in reality must have been within a range around $19-25 \mathrm{~m}$ above the sea level of that time. Within confidence limits, this would be the largest runup reconstructed anywhere for the Storrega Slide tsunami (Bondevik et al. 2005).

Regarding sea-level and tsunami impacts on our study region - Doggerland (Coles 1998) - a number of geological and geomorphological boundary conditions must be taken into consideration. Foremost is the rapid rise of sea-levels in the early Holocene. For example, in the southern North Sea (a region with minimal isostasy), sea-level rise between 9000 calBP and 7000 calBP amounts to an average value of $1.25 \mathrm{~m} / 100$ yrs (Behre 2003). In addition, several superimposed geomorphological and climatic processes (with their own time-scales) have contributed and complicated the sea-level changes during the interval of interest (Tab. 4).

\section{The timing of the Storegga Slide}

On the basis of comprehensive submarine geomorphological studies off the coast of Norway, a series of more than 50 14C-AMS-ages on monospecific planctonic foraminifera from stratified basal post-slide sediments give a direct date (weighted average) for the expected timing of the Storegga Slide emplacement of $7250 \pm 250{ }^{14} \mathrm{C}$ yrs BP (Haflidason et al. 2005), in close agreement with our summary estimate for the Storegga tsunami of about $7300{ }^{14} \mathrm{C}$ yrs BP (this paper). In Figure 2 this ${ }^{14} \mathrm{C}$-date is shown along with the early Holocene sea-level curve for the southern North Sea (Behre 2003), and the stable oxygen isotope record from the Greenland GISP2 ice core (Grootes et al. 1993). Two key observations can be made from Figure 2.

Firstly, the broad picture of sea-level rise, as shown in Figure 2 (lower box), is one of a comparatively rapid rise between $10 \mathrm{ka}$ calBP and $6 \mathrm{ka}$ calBP, followed by a significant slowing in the following millennia. The slow rise in recent millennia (since 5000 calBP) is accompanied by minor oscillations (for discussion, see Bungenstock 2006). According to Behre (2003; 2007), the sea-level curve for the southern North Sea is to some extent representative of global sea-level rises. In the southern North Sea, isostatic effects are not observed, and tectonic movements are so weak as to be irrelevant (the situation becomes more complex when Scotland and north Jutland are considered, as these areas were subject to isostatic uplift). The correlation of the ${ }^{14} \mathrm{C}$-age for the Storegga Slide and Tsunami with this sea-level curve (Fig. 2) shows that the Storegga Slide occurred at a time when the sea level in the southern North Sea stood at about $17 \mathrm{~m}$ higher than the present level.

Secondly, Figure 2 suggests that the Storegga Slide occurred during the period of the well-known ' 8200 calBP' climate event. The implications of this observation will be studied further below.

\begin{tabular}{|c|c|c|c|c|}
\hline Key Event or Process & Duration & Affected Region & Date & Reference \\
\hline Abrupt Drainage of Lake Agassiz & Months & North Atlantic & $8470 \pm 300 \mathrm{calBP}$ & Barber et al. 1998 \\
\hline Rapid rise in global sea-level by $0.2-0.5 \mathrm{~m}$ & Months & Global & $\sim 8200$ calBP & Bauer et al. 2004 \\
\hline Reduced North Atlantic Deep Water Formation & Two Centuries & Global & $8247-8086 \mathrm{calBP}$ & Thomas et al. 2007 \\
\hline Storegga Slide Tsunami & Hours & North Sea & $\sim 8150 \mathrm{calBP}$ & Bondevik 1997 \\
\hline Eustatic/isostatic Sea Level Rise & Millenia & Northwest Europe & Continuous & Lambeck 1995 \\
\hline Slow Flooding of Doggerland & Centuries & North Sea & $\sim 8000 \mathrm{calBP}$ & Behre 2003 \\
\hline Slow Final Flooding of Doggerland & Centuries & North Sea & $\sim 7000{ }^{14} \mathrm{C}-\mathrm{BP}$ & Shennan et al. 2000 \\
\hline Rapid Final Flooding of Doggerland & Hours & North Sea & $8100 \pm 100 \mathrm{calBP}$ & this paper \\
\hline
\end{tabular}

Tab. 4. Key events, processes, time scales, dates, and geographic regions. 


\section{The timing of the Storegga Slide tsunami}

In the following, we present further refinements to the temporal correlation of the Storegga Slide tsunami with contemporary sea-levels, and consider in detail the potential correlation of the tsunami with the 8200 calBP climate event. These arguments make use of CalPal-software (Weninger et al. 2003; Weninger and Jöris 2004), and the main results are displayed in Figure 3.

Figure 3 shows in high resolution the tree-ring calibrated radiocarbon date for the tsunami $(7300 \pm$ $\left.30{ }^{14} \mathrm{C}-\mathrm{BP}, 95 \%\right)$ in comparison with the Greenland $\delta 180$ ice ice-core data obtained from the GISP2-drilling (Grootes et al. 1993). The $\delta^{18} 0_{\text {ice-GISP } 2 \text { data, as }}$ shown in Figure 3, are shifted 40 years younger, in comparison to the age values published by Grootes et al. (1993). This shift is obtained by visual comparisons between different climate proxies undertaken to achieve a precise and absolute (tree-ring synchronised) reference time interval for the North Atlantic 8200 climate event sensu strictu (i.e. the Hudson Bay outflow) (Weninger et al. 2006). The 40-year shift of the GISP2 age model is supported by the recent recount of Greenland Ice Core ages in the Holocene (GICC05 age model) (Vinther et al. 2006), as well as by dedicated high-resolution studies of the 8200 calBP climate event by Thomas et al. (2007).

Following Barber et al. (1997), the sequence of events associated with the ' 8200 calBP' event is as follows: during deglaciation, a remnant ice mass blocked the northward drainage of the large glacial lakes Agassiz and Ojibway, which previously discharged southeastward over sills into the St Lawrence river. Around 8500 calBP $(8470 \pm 300$ calBP according to Barber et al. 1997), the ice dam collapsed, allowing the lakes to drain swiftly northwards into the Labrador Sea. The release of an estimated $1.6 \times 10^{14} \mathrm{~m}^{3}$ of freshwater (Teller et al. 2002) from the proglacial lakes through the Hudson Strait would have substantially weakened deep water formation in the North Atlantic (e.g., LeGrande 2006). Temperatures in the North Atlantic region decreased abruptly, with subsequent recovery over the following 200 years or so (e.g. LeGrande et al. 2006; Thomas et al. 2007). In central Greenland the surface air temperature dropped by $3-6^{\circ} \mathrm{C}$ (e.g. Johnsen et al. 2001), and perhaps up to $7.4^{\circ} \mathrm{C}$ (Leuenberger et al. 1999). A reduction in air temperature of this magnitude is likely to be linked with drier conditions and stronger winds over the North Atlantic and the surrounding land (Alley et al. 1997; Bauer et al. 2004; LeGrande 2006).

The freshwater release estimates are of importance for the present studies, since this water would lead to an abrupt rise of global-mean sea level. The estimates range from about 0.25 to $0.5 \mathrm{~m}$, with timescales of the release thought to be in the order of several months to a year (e.g. Bauer et al. 2004; LeGrande 2006).

Clearly, the exact timing of these events is of crucial importance to socio-environmental studies on the Mesolithic in north-western Europe, just as it is on
Fig. 2. Overview. TreeRing Age Calibration of 14 -Age for Storegga Slide $7250 \pm 250 \quad B P$ (Haflidason et al. 2005) shown in context of Early Holocene Sea-Level Rise in the Southern North Sea (Behre 2003) and Stable Oxygen Isotope Signature in Greenland Ice-Core GISP2 (Grootes et al. 1993). Calibration Data: Reimer et al. (2004). Calibration Methods: Weninger and Jöris (2004).

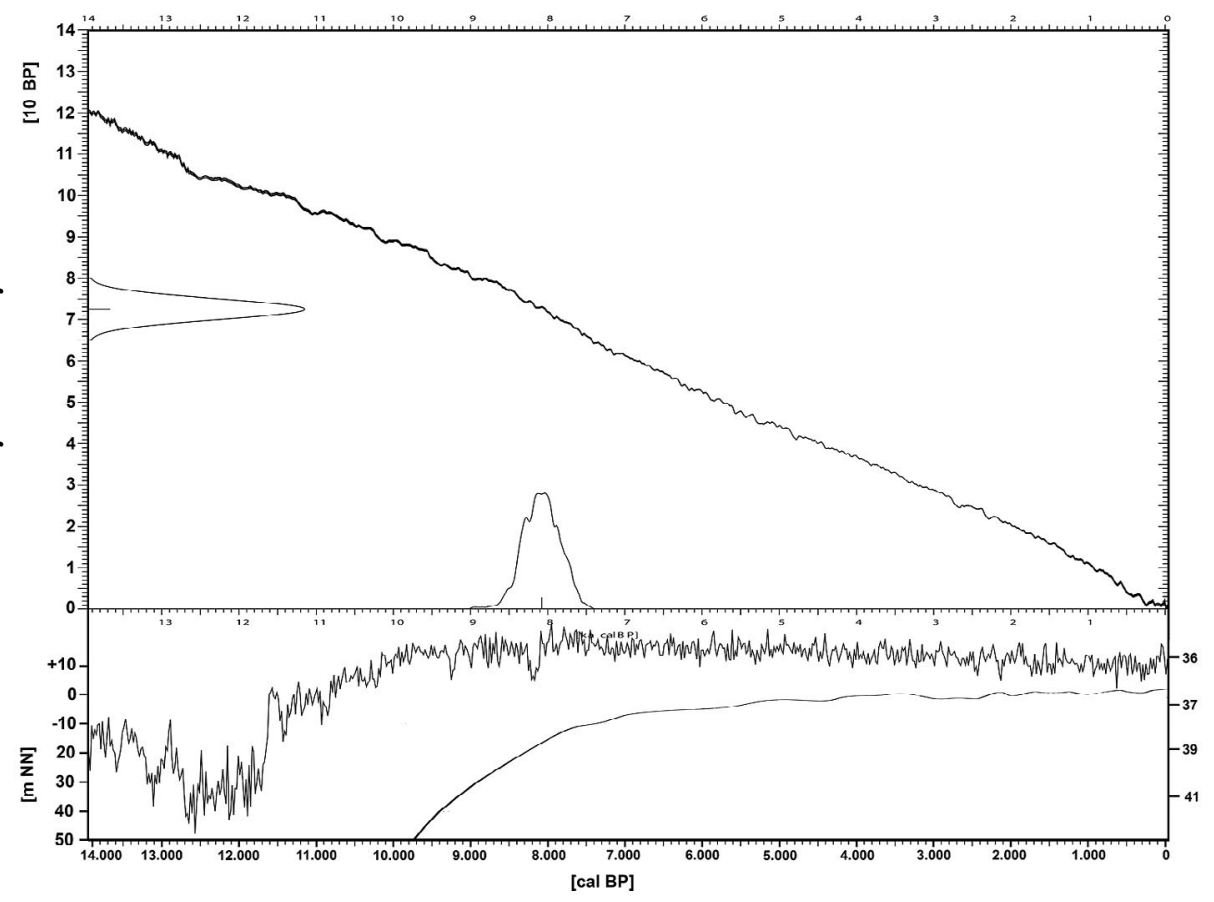




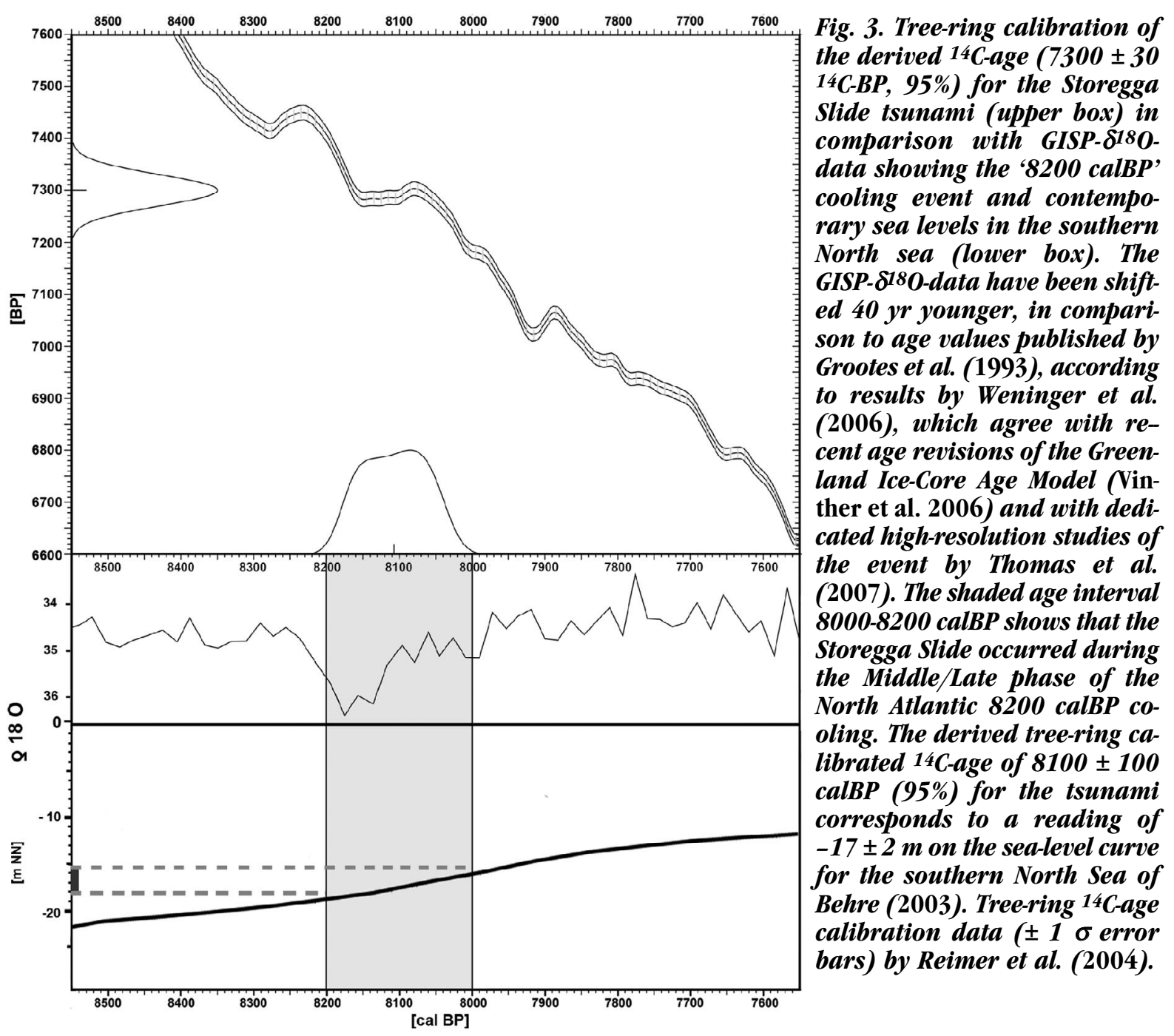

wider archaeological scales (cf. Weninger et al. 2006; Clare et al. this volume). However, the situation is complicated, since we now recognise that the '8200 calBP event' (sensu strictu: Hudson Bay outflow) is superimposed on a wider period of cooling, dating to $c$. 8600-8000 calBP (Rohling and Pälike 2005). Given the lack of sufficient temporal resolution, the signatures of actually quite different climatic and environmental processes are unfortunately quite often compounded into one 'default' signal called the ' 8200 calBP' event. However, the complexity of rapid climate change during this period is becoming clearer now, on the basis of dedicated highresolution studies. Of special interest to our study, the temporal structure of the ' 8200 calBP' cooling event has been studied in great detail by Thomas et al. (2007), who conclude that the event had an overall duration of $220 \pm 2$ years and a central, 4-yearlong spike at 8222 calBP, during which Greenland ice surface temperatures dropped by up to $13 \pm 2{ }^{\circ} \mathrm{C}$ (for comparison: cooling during the Younger Dryas amounts to approx. $15^{\circ} \mathrm{C}$ ). We make use of these re- sults in evaluating the temporal relation between the 8200 calBP climate event and the Storegga Slide tsunami, as follows.

Figure 3 illustrates that the Storegga Slide tsunami occurred, with $95 \%$ confidence, at some time during the interval $8200-8000$ calBP. We can state this is surely within the period of reduced North Atlantic Deep Water (NADW) formation and attendant circum-Atlantic cooling (8247-8086 calBP, according to Thomas et al. 2007). Dating constraints are also sufficient to state that it is unlikely that the tsunami occurred near the onset of the 8200 calBP climate event, or, in other words, the Storegga Slide was not synchronous with the Hudson Bay flood, but postdated it. Consequently, the tsunami appears to have impacted the southern North Sea at some time during the course of the 8200 calBP climate event. Further precision is impeded by the fact that the tsunami's ${ }^{14 C} \mathrm{C}$-age of $7300 \pm 30{ }^{14} \mathrm{C}-\mathrm{BP}(95 \%)$ falls into a flat region of the tree-ring calibration curve (Fig. 3). Given that reduced North Atlantic Deep Water 
(NADW) formation may cause changes in the carbon cycle that may lead to such so-called radiocarbon plateaux in the calibration curve (as modelled for the Younger Dryas, Hughen et al. 2006), this provides extra corroboration for the suggestion that the Storegga Slide occurred at some time within the 8200 calBP climate event. To conclude, the Storegga tsunami event occurred within one to two centuries after the global sea-level jump of $0.25-0.5 \mathrm{~m}$ that was associated with the Hudson Bay flood. This juxtaposition would have helped to increase the flooding impact of the tsunami in low-lying coastal regions.

\section{Palaeogeographical reconstructions: key sta- ges and events}

The large continental shelf between Britain, Norway, and the NW-European coast which is commonly known as 'Doggerland' (Coles 1998) is now completely submerged under the North Sea, but was subaerially exposed at the beginning of the Holocene. In addition, a considerable area of land was exposed off the west coast of Jutland. Due to eustatic sea-level changes, combined with glacio- and hydro-isostatic land-level changes, the former land areas were increasingly submerged during the course of the Early Holocene. Key stages in the development of Doggerland, according to reconstructions by Lambeck (1995), Shennan et al. (2000) and Behre (2003), include (i) the gradual evolution of a large tidal embayment between eastern England and Dogger Bank before $9 \mathrm{ka}$ calBP (9-8 ka $\left.{ }^{14} \mathrm{C}-\mathrm{BP}\right)$; (ii) the development of Dogger Bank as an island at high tide 8-7 ka ${ }^{14} \mathrm{C}-\mathrm{BP}$; and (iii) the final disconnection of England from the continent by $c .8 .0 \mathrm{ka}$ calBP (7-6 ka $\left.{ }^{14} \mathrm{C}-\mathrm{BP}\right)$. Prior to its complete flooding around 8000 calBP, Doggerland formed a wide, undulating plain containing a complex meandering river system, with associated channels and lakes (Gaffney et al. 2007).

Although there is general consensus that Doggerland was completely submerged by $c$. 8000 calBP, diffe-

\begin{tabular}{|l|l|l|}
\hline $\begin{array}{l}\text { 14C-Age } \\
\left.\text { [ka }{ }^{14 C-B P]}\right]\end{array}$ & $\begin{array}{l}\text { Calendric Age } \\
\text { [ka calBP] }\end{array}$ & Reference \\
\hline 8 & $9.0-8.7$ & Nordberg 1991 \\
\hline 7.6 & 8.5 & Conradsen and Heier-Nielsen 1995 \\
\hline 7.7 & 8.6 & Jiang et al. 1997 \\
\hline $8-7$ & $9.0-7.7$ & Björklund et al. 1985 \\
\hline $8-7$ & $9.0-7.7$ & Lambeck 1995 \\
\hline $8.7-8.3$ & $9.7-9.3$ & Jelgersma 1979 \\
\hline
\end{tabular}

Tab. 5. A Key Event in the History of Doggerland: The English Channel Opening (compilation by Gyllencreutz 2005a). rent authors give alternative palaeogeographic reconstructions for the history of Doggerland (Dix et al. 2008). Corresponding to the quite general lack of archaeological and palaeo-environmental data from the submerged areas, contemporary research puts the focus on the timing of selected major (key) events. An example is shown in Table 5, where Gyllencreutz (2005a) has collated published ages for the opening of the English Channel.

Note that, according to the ages given in Table 5, the English Channel was most likely open at the time of the Storegga Slide Tsunami - although this may have been a fairly recent development which had taken place just a few hundred years previously.

Summaries such as Table 5 would imply that the existence of the key event 'Opening of the English Channel' is not open to question, but that its age is. However, there is a higher level of complexity. It is important to recognise not only that intensive research may result in different apparent dates for the same (or similar) events, but also that the illustrated approach relies on an underlying assumption that an event (e.g. the flooding of Doggerland) is actually well-described by the dates. There is a strong emphasis in contemporary studies on dating key events as a widespread method to describe the history of Doggerland. Lambeck (1995) argues that the English Channel was established as an open marine waterway by about $7500{ }^{14} \mathrm{C}$-yrs BP (8600 calBP). According to Shennan et al. (2000), at this time Dogger Bank was still an island at high tide, while the channel separating northern Norfolk from mainland Europe was $5-10 \mathrm{~m}$ deep. At the same time, wide intertidal areas and saltmarsh lowlands are predicted for areas to the east of Norfolk (Shennan et al. 2000). During these centuries, according to Behre (2003; 2005), the sea level in the southern North Sea rose at the enormous rate of more than $1 \mathrm{~m}$ per century. The southern North Sea had become fully marine by $7000{ }^{14}$ C-yrs BP (7840 calBP) (Lambeck 1995). Very similar results, with the focus on the timing of the 'fully marine' North Sea, were reported by Shennan et al. (2000).

Recent work has taken an entirely different approach to reconstructing the history of Doggerland, building on the unique opportunities offered by 3D seismic analysis of submerged North Sea sediments, as made available by petroleum-exploration companies (Fitch et al. 2005; Gaffney et al. 2007). The available data demonstrate the existence 
in the submerged North Sea of complex meandering river systems, with major and secondary channel belts, tunnel valleys, possible estuarine or intertidal settings, sand banks, and lakes, as revealed at high vertical and horizontal resolution at different depths, times, and stratigraphic settings, for the Early Holocene deposits (Fitch et al. 2005; Gaffney et al. 2007). However, before integrating the bathymetric and 3D seismic data, we must await additional information, especially concerning the precise timing of the different stratigraphic settings. As was stated by Coles (1998), there remains the 'intriguing' question of whether the sediments in the southern North Sea show signs of impact by the Storegga Slide tsunami.

\section{An explorative bathymetric 3D digital elevation model for Doggerland}

With this question in mind, and wishing to evaluate the potential environmental and social impact of the tsunami, we have undertaken further explorative studies to assess the impacted coastlines, with the results shown in Figure 4. These results are based on (i) the derived date for the tsunami event of $7300 \pm$ $30{ }^{14} \mathrm{C}-\mathrm{BP}(8100 \pm 100$ calBP; $95 \%)$ ( $c f$. Fig. 1), (ii) the hypothetical sea-level height of $-17 \pm 2 \mathrm{~m}(95 \%)$ NN for the southern North Sea at this time ( $c f$. Fig. 3 ), but extended to cover bathymetric depths of -17 $\pm 5 \mathrm{~m}$ (see below), and (iii) the palaeo-coastlines at this time, as interpolated from the reconstructions of Shennan et al. (2000) and Behre (2003).

In detail, our reconstruction of the impacted areas as shown in Figure 4 is based on the following data and methods. From the different coastlines, defined by these authors for different stages in the development of Doggerland, we first selected coastlines dating as closely as possible to the tsunami event. As shown above, these coastlines are typically defined for 'key events', between which we must now interpolate. For the tsunami age of $7300 \pm 3014 \mathrm{C}-\mathrm{BP}$ $(8100 \pm 100$ calBP) there are two such (closest) coastlines, which give us an event-sandwich: firstly, the coast-line defined $c .200{ }^{14} \mathrm{C}$-yrs before the tsunami event (Shennan et al. 2000.Fig.5d: $7500{ }^{14} \mathrm{C}-$ BP) and, secondly, the coastline $c .200{ }^{14} \mathrm{C}$-yrs after the tsunami (Shennan et al. 2000.Fig.5d: $7000{ }^{14} \mathrm{C}$ BP). Although very similar coastlines can be read from the palaeo-geographic reconstructions of Doggerland given by Behre (2003), we decided to base our reconstructions on Shennan et al. (2000), if only for the simple reason that the coastlines in this publication are defined using uncalibrated ${ }^{14} \mathrm{C}$-ages of 7500 and $7000{ }^{14} \mathrm{C}-\mathrm{BP}$, which simplifies our visual interpolation for the nearly exactly intermediate value of $7300{ }^{14} \mathrm{C}-\mathrm{BP}$.

The first step in map construction, then, was to digitize the coastlines from the colour graphs of Shennan et al. (2000) for $7500{ }^{14} \mathrm{C}-\mathrm{BP}$ and $7000{ }^{14} \mathrm{C}-\mathrm{BP}$. They are shown as thin lines in Figure 4. They are used as a basic reference for the coasts of Doggerland 'before' and 'after' the tsunami event. Note that we do not imply that the tsunami was responsible for reshaping the Doggerland coasts. The adopted coastlines were then projected as shapefiles onto a map of the North Sea based on a 3D digital elevation model using unedited SRTM (Shuttle Radar Topography Mission) data. Since this data is unedited, it contains occasional voids, gaps, or streaks, where the terrain lay in the radar beam's shadow or in areas of extremely low radar backscatter where an elevation solution could not be found. Such streaks are evident in Figure 4 for the SRTM30 tile we use, which is named w020n90 by the USGS (United States Geological Survey 2008). This tile has a horizontal grid spacing of 30 arc seconds (approximately 1 kilometre). The data is expressed in geographic coordinates (latitude/longitude) and is referenced to the World Geodetic Survey (WGS) system of 1984 (WGS84). We used Globalmapper (www.globalmap per.com) to construct the map.

The next step was to find an interpolation between these two coastlines that would be representative of the coastline at $7300{ }^{14} \mathrm{C}-\mathrm{BP}$, the time of the Storegga Slide tsunami. Rather than applying a direct interpolation between the two given coastlines, we applied an explorative method, based on the calculation of a set of bathymetric contours using the SRTMdata, at intervals of $1 \mathrm{~m}$ between $-30 \mathrm{~m}$ and $-10 \mathrm{~m}$. These contours were projected onto the same map as previously used for the two coastline shapefiles derived from Shennan et al. (2000) for ages 'before' and 'after' the tsunami. As shown in Figure 4 using an appropriate colour ramp to show areas potentially 'above' and 'below' the contemporary sea-level, it was possible to approximate the coastlines of Shennan et al. (2000) for Dogger Bank solely based on SRTM $1 \mathrm{~m}$ bathymetric contours. The final step was to colour shade the interpolated areas according to their bathymetric depth, in relation to the two reference coastlines derived from the studies of Shennan et al. (2000). It is encouraging that quite similar reconstructions are obtained from the maps of Doggerland, as published by Behre (2003), for the timewindow under study. We emphasise that the precision and accuracy of the maps obtained by this pro- 


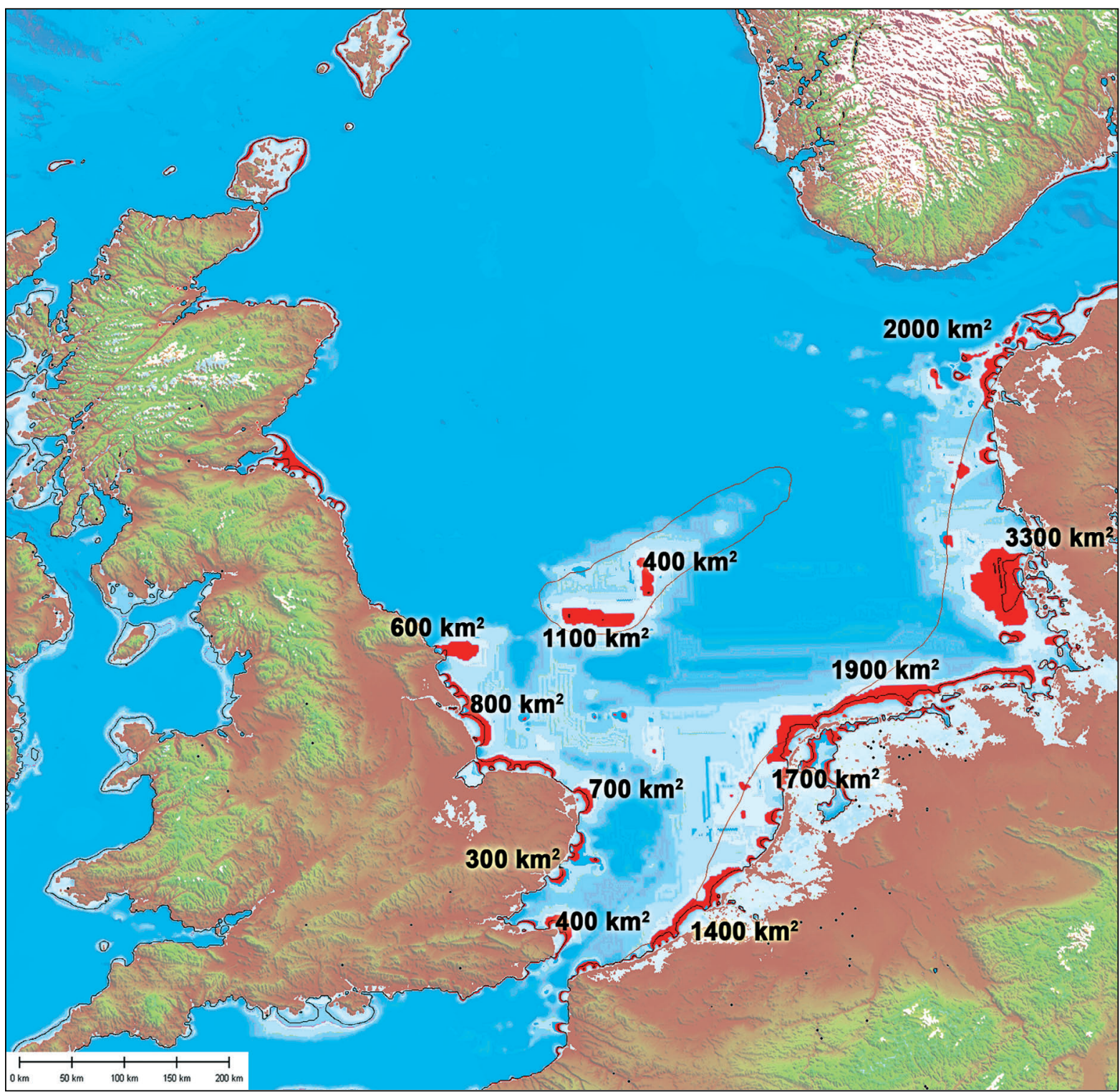

Fig. 4. Hypothetical regions with major impact by the Storegga Slide tsunami. Ocean colour shading is based on SRTM bathymetric data (United States Geological Survey 2008; cf. text). Major individual hypothetical tsunami impact areas, represented by the SRTM-bathymetric depth interval $-17 \pm 5 \mathrm{~m}$, are shaded red. Due to applied reconstruction and specific colour shading approach, red shaded areas represent lowlying 'run-in' areas. These are not identical to potentially even more dangerous 'run-up' areas (cf. text). Thin brown lines represent digitized palaeogeographic coastlines according to Shennan et al. (2000), but slightly changed to allow for minor differences vs the reconstructions given by Behre (2003). Together, these two coastlines approximate Doggerland some 20014 C-yrs 'before' and 'after' the tsunami event. For simplicity, the Doggerbank 'island' is only shown for the date c. $7500{ }^{14} \mathrm{C}$-BP. Whether this 'island' was really subaerial, or not, at the time of the tsunami, cannot be decided with given data.

cedure is not limited to that of the palaeo-coastlines used in their calibration. Although these are extremely useful for orientation purposes, they do not enter the final reconstruction (Fig. 4). Instead, assuming the correlation between the derived date for the tsunami and the contemporaneous sea-level is accepted, we recognise as a major limiting factor our lack of knowledge concerning the post-tsunami sedimentational processes that surely occurred in the regions under study. One main result of this study is the (unexpectedly) high tsunami impact assigned to the western regions of Jutland, and in particular to the northern coasts of Jutland opposite Norway (Fig. 4). Due to the given combination of shallow flats and steep coastal channels, these coasts are especially vulnerable to the different kinds of destructive energy contained in the tsunami (see below). 


\section{Tsunami physics and palaeogeographic impact scenarios}

A detailed description of tsunami impacts on coastal lowlands is beyond the scope of the present paper, and we suffice with a brief recapitulation of the general physical principles underlying a tsunami impact, following Dawson (2008). We interpret those processes within the context of the configuration of the palaeo-landscapes under study in the southern North Sea.

The impacts of a tsunami depend most strongly on coastal shape. For steep coastlines, such as the fjords and estuaries of East Scotland, the physical effects are best expressed in terms of runup, which is defined as the maximum height reached by the head of the tsunami wave. However, on the more gently inclined coastlines, mud-flats, salt-marshes and gently rolling plains of Mesolithic Doggerland, it would be more appropriate to take the maximum width of the inundated zone (or 'run-in') as a measure of the scale of the energetic impact. For such gently inclined areas, the extent of the inundated area is limited not by the maximum height of the wave, but by frictional forces, drag and turbulence, as the wave advances and retreats over the more or less rough surface. In such settings, a tsunami initially appears more like an unusually extensive flood, rather than a giant wave. The water body first develops its huge destructive potential at the moment the wave breaks. This can already occur at some distance from the coast, as shown by eyewitness accounts on Flores Island of the 1992 Indonesian tsunami (Shi and Smith 2003). On Flores Island, already along a comparatively short coastline of some $100 \mathrm{~km}$, runup heights varied mostly between 1.5 and $4 \mathrm{~m}$, but runup reached as high as $26 \mathrm{~m}$ at one location (Riangkrok), due to local underwater bathymetry and coastline configuration (Shi and Smith 2003).

The extent of the (catastrophically) flooded area further depends strongly on local vegetation (e.g. sand, grass, peat, schrubs, trees) and local topography (e.g. sandbanks, slopes, smaller and larger water channels). As documented for the 1992 Indonesian tsunami, this combination of major 'runin' and locally extreme 'runup' effects could also be expected for the Storegga Slide tsunami in the southern North Sea, and here most likely in the fjords of Jutland, or in the tunnel valleys found by 3D-seismic surveying in Late Holocene Doggerland (Fitch et al. 2005). In search of these areas, a closer look at Figure 4 reveals that quite a number of the red areas indeed put focus on such coastal sections (recognisable by the bending-in of the red areas), where underwater bathymetry would magnify the incoming waves. This differential vulnerability of palaeo-coastlines is clearly an important topic (e.g. Shi and Smith 2003), although beyond the scope of the present paper. We are confident that, allowing for such effects, the hypothetical tsunami 'run-in' impact map (Fig. 4) supports a conservative assessment of potential tsunami 'danger zones'.

As a final topic to address, due their long wavelengths in deep water, tsunamis will refract around large obstacles, such as islands. Hence, depending strongly on the sea level of the time, the Storegga Slide tsunami may either have dissipated its energy on the northern side of the Dogger Bank, if this region was indeed an island with a height above around $5-10 \mathrm{~m}$, or - if the Dogger Bank was submerged already - the tsunami may have reached the coasts of Belgium, the Netherlands and North Germany. Based on the reconstruction shown in Figure 4 , and in view of all the data entered, interpolations, literature, and methods, this latter scenario seems the most probable. As shown below, this conclusion is further corroborated by available ${ }^{14} \mathrm{C}$-ages measured on finds dredged up from the southern North Sea.

\section{Radiocarbon data from the southern North Sea}

Numerous Pleistocene and Holocene faunal remains have been dredged up from the southern North Sea, particularly in recent years (Mol et al. 2006; 2008), including worked bone and antler implements, some of which have been directly dated to the Early Mesolithic (Tab. 6), while other finds can be assigned to this period typologically. Even more dramatic evidence has emerged in the form of human skeletal remains dredged from many kilometres offshore and directly dated to the Early Mesolithic (Glimmerveen et al. 2004; Mol et al. 2008) (Tab. 6).

Abundant faunal remains and artefacts have also been found close to shore in the Netherlands (Louwe Kooijmans 1971; Verhart 2005) and both inshore and offshore along the west coast of Jutland (Fischer 2004.Fig. 3.3).

Although surely not the last word, since it is impossible to generalize from the present small (but beautiful) database of finds from the North Sea (cf. Glimmerveen et al. 2004; Mol et al. 2008), we need but a quick look at the available ${ }^{14} \mathrm{C}$-ages to conclude 
that these do not provide evidence for habitation of Doggerland, at ages younger than $c .8000{ }^{14} \mathrm{C}-\mathrm{BP}$.

For completeness, we must comment on the reference to 'Andersen (pers comm)' given by Coles (1999.57) and repeated by Behre (2003.41), as well as by Behre (2005.210), concerning a worked bone dredged from Dogger Bank dating to ' 6050 calBC' (Coles 1999.57) resp. '6050 v.Chr.' (Behre 2003.41; 2005.210). This date was long suspect to the present authors, since it seemed to indicate a very late final flooding of Dogger Bank, perhaps even synchronous with the Storegga Slide tsunami. If validated, this date would have directly falsified our reconstruction (Fig. 4), at least give reason to assume a much larger Doggerland at this time. However, the date itself does not survive critical scrutiny. According to Søren Andersen (pers comm to B.W., 15 ${ }^{\text {th }}$ April 2008), it is simply misquoted.

\section{Mesolithic palaeodemography}

Since the pioneering studies of Coles (1998), it is beyond credence that Doggerland was an inhabited landscape during the Late Palaeolithic and earlier Mesolithic periods. In terms of estimating the impact of the Storegga slide event on contemporary human populations, results will depend strongly on the extent of the area impacted, the severity of the tsunami over this area, and the density and distribution of human settlement (Fig. 5). Average population densities for Mesolithic northwest Europe, based largely on ethnographic analogy, have been estimated on the order of 0.05 to 0.10 person $/ \mathrm{km}^{2}$ (Binford 2001; Constandse-Westermann and Newell 1989; Rozoy 1978). However, the population would not have been evenly distributed over Doggerland, and we can propose with some confidence that coastal, lacustrine and riverine areas would have experienced substantially higher population densities ( $F i$ scher 1997; Paludan-Müller 1978), perhaps to the order of 0.50 to 1.0 person $/ \mathrm{km}^{2}$ (cf. Schulting in press), while areas further inland (away from resources) would have been relatively sparsely populated. There exists some stable isotope and archaeological evidence in support of these notions (Schulting in press; Schulting and Richards 2001).

Since it is precisely the coastal and near-shore riverine areas (the latter because of a funnelling effect up coastal river valleys) that would have been most affected by the Storegga tsunami, there may have been considerable impact on the contemporary population. For example, one of the most notable geo-

\begin{tabular}{|c|c|c|c|c|c|c|}
\hline Location & Species & Element & Lab no. & ${ }^{14} \mathrm{C}-\mathrm{BP}$ & $\begin{array}{l}\text { Calendric Age } \\
\text { [calBP] }(68 \%)\end{array}$ & References \\
\hline Leman \& Owen & Celaphus & antler harpoon & OxA-1950 & $11740 \pm 150$ & $13640 \pm 200$ & (4) \\
\hline S Bight, North Sea & Bos primigenius? & decorated metapodial & GrA-28364 & $11560 \pm 50$ & $13460 \pm 80$ & (3) \\
\hline S Bight, North Sea & $A$ alces & worked antler & GrA-27206 & $9910 \pm 50$ & $11350 \pm 90$ & (3) \\
\hline S Bight, North Sea & $H$ sapiens & mandibula & GrA-23205 & $9870 \pm 70$ & $11330 \pm 100$ & (2) \\
\hline $52^{\circ} 10^{\prime} \mathrm{N}, \mathrm{O} 2^{\circ} 49^{\prime} \mathrm{E}$ & $H$ sapiens & cranium & UtC-3750 & $9640 \pm 400$ & $11110 \pm 620$ & (1) \\
\hline S Bight, North Sea & A alces & worked antler & GrA-37004 & $9520 \pm 50$ & $10880 \pm 150$ & (3) \\
\hline S Bight, North Sea & Sus scrofa & humerus & UtC-7886 & $9450 \pm 70$ & $10790 \pm 180$ & (2) \\
\hline S Bight, North Sea & $H$ sapiens & humerus & GrA-27188 & $9140 \pm 50$ & $10320 \pm 70$ & (3) \\
\hline S Bight, North Sea & $H$ sapiens & humerus & GrA-30733 & $9080 \pm 50$ & $10250 \pm 40$ & (3) \\
\hline S Bight, North Sea & $H$ sapiens & humerus & GrA-31287 & $9035 \pm 40$ & $10210 \pm 30$ & (3) \\
\hline S Bight, North Sea & $H$ sapiens & humerus & GrA-35949 & $9005 \pm 45$ & $10140 \pm 90$ & (3) \\
\hline $52^{\circ} 22^{\prime} \mathrm{N}, 03^{\circ} 06^{\prime} \mathrm{E}$ & Celaphus & 1st $_{\text {st }}$ halanx & GrA-20256 & $8820 \pm 60$ & $9920 \pm 160$ & (2) \\
\hline Eurogeul & C capreolus & worked antler? & GrA-33949 & $8405 \pm 45$ & $9420 \pm 60$ & (3) \\
\hline $53^{\circ} \mathrm{OO} 0^{\prime} \mathrm{N}, \mathrm{O}^{\circ} 54^{\prime} \mathrm{E}$ & $H$ sapiens & mandible & GrA-11642 & $8370 \pm 50$ & $9390 \pm 70$ & (2) \\
\hline $52^{\circ} 27^{\prime} \mathrm{N}, 02^{\circ} 55^{\prime} \mathrm{E}$ & Celaphus & $2^{\text {nd }}$ phalanx & GrA-20353 & $8350 \pm 50$ & $9370 \pm 70$ & $(2)$ \\
\hline S Bight, North Sea & $H$ sapiens & cranium & UtC-624 & $8340 \pm 130$ & $9300 \pm 150$ & (2) \\
\hline S Bight, North Sea & $A$ alces & worked antler? & GrA-30731 & $8240 \pm 45$ & $9220 \pm 80$ & (3) \\
\hline S Bight, North Sea & $H$ sapiens & humerus & GrA-27205 & $8180 \pm 45$ & $9140 \pm 90$ & (3) \\
\hline Eurogeul & Celaphus & modified antler & GrA-22999 & $8070 \pm 50$ & $8950 \pm 110$ & $(2)$ \\
\hline Eurogeul & $A$ alces & antler & GrA-23201 & $7970 \pm 60$ & $8830 \pm 120$ & (2) \\
\hline
\end{tabular}

Tab. 6. Final Upper Palaeolithic and Mesolithic dates on human and faunal remains dredged from the North Sea. Sources: 1 - Erdbrink and Tacoma 1997; 2 - Glimmerveen et al. 2004; 3 - Mol et al. 2008; 4 Gillespie et al. 1984. According to Glimmerveen (pers. comm) most of the finds from the Southern Bight originate southwest of the Brown Bank and have the following approximate coordinates: $52^{\circ} 34^{\prime} N$, 02 ${ }^{\circ} 35^{\prime} 5^{\prime}$ E. Calibrated using CalPal (http://www.calpal.de). 
morphological features in a recent 3D-seismic mapping exercise of the southern North Sea is the presence of a central lake known as the 'Outer Silver Pit' (Gaffney et al. 2007). Briggs et al. (2007) interpret two elongate ridges within the Pit as sand banks that formed in an estuarine environment during the Early Holocene transgression, inferring from this the presence of strong tidal currents in the north-facing estuary. Following Donovan (1975), these tidal cur- rents may have been in part responsible for the formation of the Outer Silver Pit depression itself. Similar estuarine features are well-known from the sea floor in the Danish archipelago, where they support numerous Mesolithic settlements (Fischer 2004). They would have, (i) attracted a concentration of Mesolithic settlements (Fischer 1997; 2004) and (ii), been heavily impacted by a channelling of energy during the impact of the Storegga tsunami.

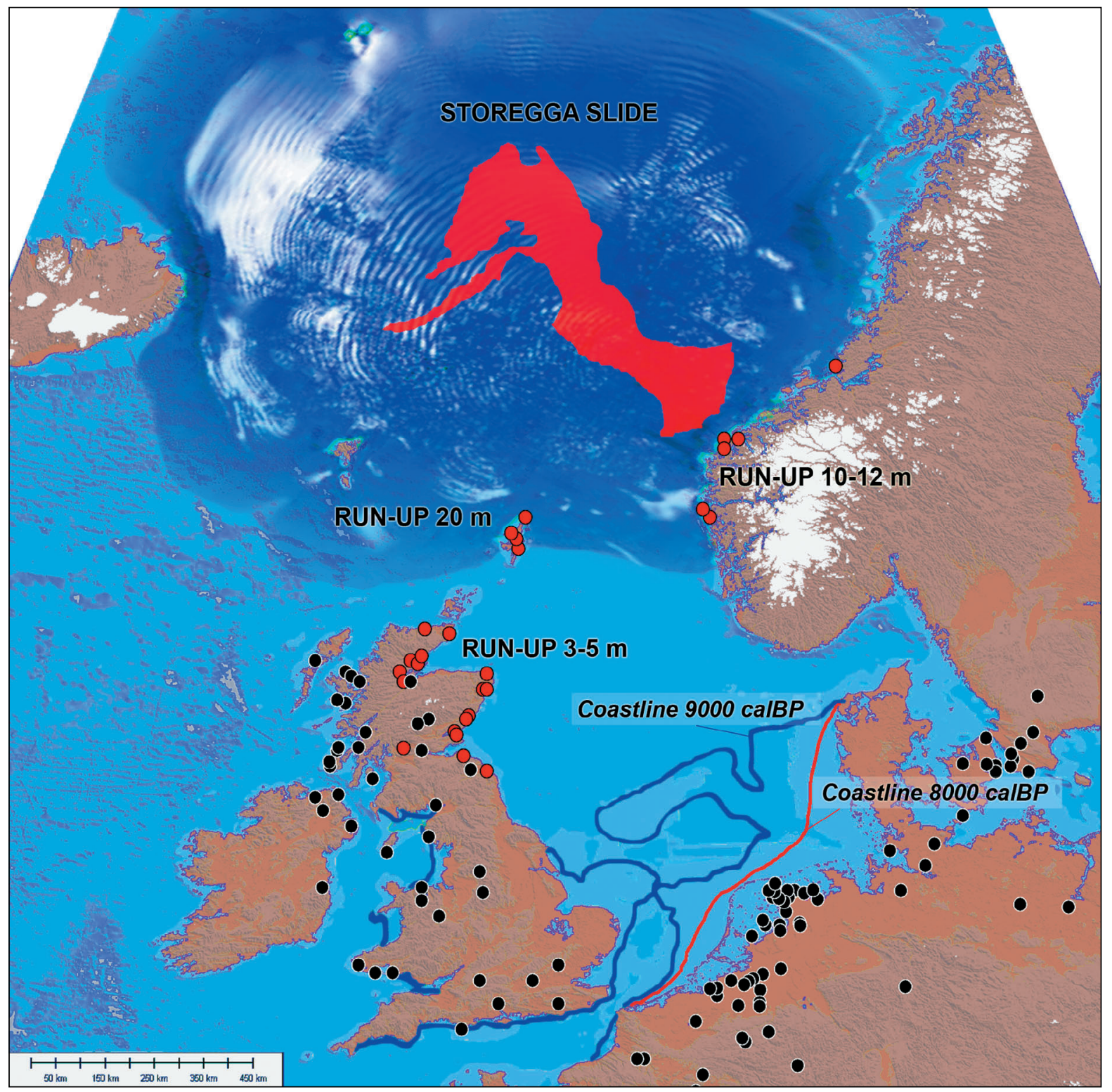

Fig. 5. Early Holocene palaeogeography of the Northwest European continental shelf ('Doggerland') and geographic distribution of ${ }^{14}$ C-dated Mesolithic sites in Northwest Europe for the time-window $7600-7000$ ${ }_{14}$ C-BP. Palaeogeographic coastlines according to Shennan et al. (2000) and Behre (2003), with colour shading on the base of SRTM bathymetric data (cf. text). Radiocarbon-dated Mesolithic sites according to Weninger et al. in press) shown as black dots. Red dots indicate sites with radiocarbon-dated tsunami deposits (cf. Appendix, Tab.8). Area of the submarine Storegga Slide digitized and georeferenced according to Bondevik et al. (2003) shown red. Modelled wave for the Storegga tsunami taken from Bondevik et al. (2005), adapted and projected onto the map graphically, with no vertical scaling. The modelled tsunami wave has a height of 3 m on the open ocean (Bondevik et al. 2005) and is likely to have reached the southern North Sea with this height (Bondevik, pers. comm. 2007) 
Table 7 presents various possible scenarios for the number of individuals affected by the Storegga tsunami, based on the 'danger areas' shown in red in Figure 4. As a first approximation, and assuming that half of the area under threat was severely impacted, it can be suggested that some 700 to 3000 individuals were affected. This number is sufficiently large to have potentially re-

\begin{tabular}{|l|c|c|c|c|c|}
\hline & area $\left.\mathbf{( k m}^{2}\right)$ & \multicolumn{4}{|c|}{ Population density (person/ $\left.\mathbf{k m}^{\mathbf{2}}\right)$} \\
\hline & & 0.05 & 0.10 & 0.50 & 1.00 \\
\hline Total area under threat & 13600 & 680 & 1360 & 6800 & 13600 \\
\hline $1 / 2$ area & 6800 & 340 & 680 & 3400 & 6800 \\
\hline $1 / 4$ area & 3400 & 170 & 340 & 1700 & 3400 \\
\hline
\end{tabular}

Tab. 7. Estimated population sizes in the study area affected by the Storegga tsunami at various population densities. The most likely scenario may be a population density of 0.10 to 0.50 person $/ \mathrm{km}^{2}$ over an impacted area of some $6800 \mathrm{~km}^{2}$, affecting some 700 to 3000 people, both directly and indirectly (see text).

sulted in the extinction of a number of local bands, or possibly even a regional dialectical tribe (cf. Newell et al. 1990.table 13). This does not necessarily imply that all were killed immediately, although given the likely rapidity and scale of the event, a significant number of people would almost certainly have been caught and drowned by the inexorably rising waters, while many others would have been displaced. Nor would the consequences be limited to the wave's immediate impact, as productive coastal areas could have been devastated, shellfish beds destroyed and covered by sands, together with any fixed fishing facilities, well-attested for the Late Mesolithic Ertebølle period (Pedersen 1997), but also known from the early Kongemose (c. 8300 calBP) in Denmark ( $F i$ scher 2004). Moreover, depending on the time of year that the wave hit, any stored foods meant to last over the winter may also have been lost ( $c f . S p i$ kins 2008), with subsequent starvation among survivors. Indeed, macrofossil analysis of fish bone and twigs from deposits in Norway has shown that the tsunami probably occurred during late autumn (Bondevik et al. 1997). It is conceivable, particularly in the context of continuing rising sea-levels at this time, that the final abandonment of the remaining remnants of Doggerland as a place of permanent habitation by Mesolithic populations was brought about by the Storegga tsunami.

Thus, both the immediate and longer-term affects of this event, in terms of population redistribution and social memory would have been considerable, although it remains difficult to provide more specific details at this stage ( $c f$. Coles 1998; Waddington 2007; Ward et al. 2006). One clear effect of the final separation of Britain and the continent is a strong impression of insularity in the former, seen most clearly in the absence in Britain of the trapeze armatures that dominate later Mesolithic microlith industries on the adjacent continent from $c .8500$ calBP (Jacobi 1976). Incidentally, this date is consistent with some of the more recent estimates given by palaeo-environmental researchers for the formation of the English Channel (see Tab. 5), and could even be interpreted as providing independent corroboration. While the process thus appears to have already been well underway, the Storegga tsunami may have finally severed any remaining (e.g. tidal) link between England and the continent.

\section{Discussion and conclusions}

We have assembled a large amount of $14 \mathrm{C}$-radiometric evidence for the Storegga Slide and its attendant tsunami, ranging from Norway to the British Isles. We find that the Storegga Slide tsunami event is reliably and accurately dated to $7300 \pm 30{ }^{14} \mathrm{C}-\mathrm{BP}(\mathrm{p}$ $=95 \%)[8100 \pm 100 \mathrm{calBP}]$. We then combined this with published palaeogeographic reconstructions for the now submerged Northwest European continental shelf known as 'Doggerland' (Coles 1998; Behre 2003) and regional sea-level records for the southern North Sea (Behre 2003) to evaluate the potential environmental and social impact of the tsunami in the Doggerland region. During the time-interval 82008000 calBP, the coastal lowlands of North Germany and the Netherlands were being steadily inundated by rising sea-levels due to a combination of eustatic and isostatic processes (amounting to a rise of $1.25 \mathrm{~m}$ per century, Behre 2003). In addition, there would have been an abrupt $0.25-0.5 \mathrm{~m}$ sea-level jump at around 8300 calBP, marking the sea-level effects of the catastrophic meltwater release from Lake Agassiz that triggered the so-called ' 8200 calBP' cold event around the Atlantic (e.g. LeGrande 2006; Clare et al., this issue). Simply stated, due to this coincidence, it may have been unusually cold and windy on the remaining coasts of Doggerland.

In the Netherlands (especially the northern part of the country, i.e. north of the Rhine), at the time of the Storegga Slide tsunami, and again essentially simultaneous with the 8200 calBP climate event, the number of available ${ }^{14} \mathrm{C}$-dates is very low when compared to the earlier and final part of the Mesolithic. This temporal patterning seems to correspond with 
a shift in emphasis of settlement location towards the central and western part of the area (Niekus 2006). However, the process of a drop in the number of dates begins $c .300$ years earlier than the tsunami, and $c .200$ years earlier than the North Atlantic 8200 calBP cold event, and at present we see no causal relation between these natural processes and the drop in the number of dates. Furthermore, according to Raemaekers and Niekus (in press), it would be better to interpret the observed patterns as a demise in ${ }^{14} \mathrm{C}$ dates in the higher areas, instead of a true shift in occupation, especially since there are several major biasing factors that should be taken into account when discussing spatio-temporal patterning in the northern Netherlands (discussed in more detail in Niekus 2006). It seems most likely, however, that the Mesolithic population in the area were reacting to the steadily rising ground-water levels at this time (Niekus 2006).

Similar population relocation - in reaction to the loss of vital hunting and fishing grounds - may also be expected for the steadily sinking Doggerland. Unfortunately, due to major syn-sedimentary processes in the southern North Sea (Fitch et al. 2004; Gaffney et al. 2007; Dix et al. 2008) it is not yet possible to reliably reconstruct the ancient topography of Mesolithic Doggerland itself solely on the base of modern bathymetric data, let alone reconstruct the exact coastlines for the time-window of 8200-8000 calBP.

By comparing two alternative scenarios, based on 'highest possible' and 'lowest possible' sea levels (ra- ted at $-17 \pm 5 \mathrm{~m}$ asl) that are contemporary with the derived date for the tsunami ( $8100 \pm 100$ calBP, $95 \%$ confidence) according to the sea-level curve of Behre (2003) for the southern North Sea, we conclude that the Storegga Slide tsunami would have had a catastrophic impact on the contemporary coastal Mesolithic population. One main result of this study is the high tsunami impact assigned to the western regions of Jutland, and in particular to the northern coasts, where Storegga Slide deposits may be expected, depending on locality, with strong postglacial isostatic working against rapid sea-level rise (Fischer 2004). Following the Storegga Slide tsunami, it appears, Britain finally became separated from the continent and, in cultural terms, the Mesolithic there goes its own way.
This study makes use of high-resolution 3D-digital satellite data from the SRTM (Shuttle Radar Topography) mission, flown in February 2000. This data is freely available for scientific research. We would like to express our sincere thanks to everyone involved in data accumulation, processing, and distribution. Jan Glimmerveen (The Hague, Netherlands) is personally thanked for providing ${ }^{14} \mathrm{C}$-dates on finds from the North-Sea. We extend our personal thanks to Bryony Coles (Exeter, Great Britain), Søren Andersen (Højbjerg, Denmark), Stein Bondevik (Bergen, Norway), and Martin Street (Neuwied, Germany) for helpful information.

\section{REFERENCES}

ALLEY R. B., MAYEWSKI P. A., SOWERS M., STUIVER M., TAYLOR K. C., CLARK P. U. 1997. Holocene climate instability: A prominent, widespread event $8200 \mathrm{yr}$ ago. Geo$\log y$ 25(6): 483- 486 .

BALLANTYNE C. K. 2004. After the Ice: Paraglacial and Postglacial Evolution of the Physical Environment of Scotland, 20,000 to 5000 BP. In A. Saville (ed.), Mesolithic Scotland and its Neighbours. The Early Holocene Prehistory of Scotland, its British and Irish Context, and some Northern European Perspectives. Society of Antiquaries of Scotland. Edinburgh: 27-53.

BAUER E., GANOPOLSK A., MONTOYA M. 2004. Simulation of the cold climate event 8200 years ago by meltwater outburst from Lake Agassiz. Paleoceanography 19.
BARBER D. C., DYKE A., HILLAIRE-MARCEL C., JENNINGS A. E., ANDREWS J. T., KERWIN M. W., BILODEAU G., McNEELY R., SOUTHON J., MOREHEAD M. D., GAGNON J.-M. 1997. Forcing of the cold event of 8,200 years ago by catastrophic drainage of Laurentide lakes. Nature 400: 344348.

BEHRE K.-E. 2003. Eine neue Meeresspiegelkurve für die südliche Nordsee. Transgressionen und Regressionen in den letzten 10.000 Jahren. In E. Strahl, F. Bungenstock, J. Ey, S. Wolters, R. Kiepe, L. Spath (eds.), Probleme der Küstenforschung im südlichen Nordseegebiet. (Niedersächsisches Institut für historische Küstenforschung), Iseensee Verlag. Oldenburg: 9-63. 
2005. Die Einengung des neolithischen Lebensraumes in Nordwestdeutschland durch klimabedingte Faktoren: Meeresspiegelanstieg und grossflächige Ausbreitung von Mooren. In D. Gronenborn (ed.), Climate Variability and Culture Change in Neolithic Societies of Central Europe, 6700-2200 cal BC. RGZM-Tagungen Band 1. Verlag des Römisch-Germanischen Zentralmuseums Mainz. Mainz: 209-220.

2007. A new Holocene sea-level curve for the southern North Sea. Boreas 36: 82-102.

BINFORD L. R. 2001. Constructing Frames of Reference. University of California Press. Berkeley.

BJÖRKLUND K. R., BJØRNSTAD H., ERLENKEUSER H., HENNINGSMOEN K. E., HØEG H. I., JOHNSEN K., MANUM S. B., MIKKELSEN N., NAGY J., PEDERSTAD K., QVALE G., ROSENQVIST I. T., SALBU B., SCHOENHARTING G., STABELL B., THIEDE J., THRONDSEN I., WASSMAN P., WERNER F. 1985. Evolution of the upper Quaternary depositional environment in the Skagerrak: A synthesis. Norsk Geologisk Tidsskrift 65: 139-149.

BONDEVIK S. 2003. Storegga tsunami sand in peat below the Tapes beach ridge at Harøy, western Norway, and its possible relation to an early Stone Age settlement. Boreas 32: 476-483.

BONDEVIK S., SVENDSEN J. I., JOHNSEN G., MANGERUD J., KALAND P. E. 1997. The Storegga tsunami along the Norwegian coast, its age and runup. Boreas 26: 29-53.

BONDEVIK S., MANGERUD J., DAWSON S., DAWSON A., LOHNE Ø. 2003. Record-breaking Height for 8000-YearOld Tsunami in the North Atlantic. EOS Trans. AGU 84 (31): 289-300.

BONDEVIK S., LØVHOLT F., HARBITZ C., MANGERUD J., DAWSON A., SVENDSEN J. I. 2005. The Storegga Slide tsunami - comparing field observations with numerical observations. Marine and Petroleum Geology 22: 195-208.

BONDEVIK S., LOYHOLT F., HARBITZ C., STORMO S., SKJERDAL G. 2006. The Storegga Slide Tsunami - Deposits, Run-up Heights and Radiocarbon Dating of the 8000Year-Old Tsunami in the North Atlantic. Eos Trans. $A G U$ 87(52), Fall Meet. Suppl., Abstract 0S34C-01.

BOOMER I., WADDINGTON C., STEVENSON T., HAMILTON D. 2007. Holocene coastal change and geoarchaeology at Howick, Northumberland, UK. The Holocene 17 (1): 89104.

BRIGGS K., THOMSON K., GAFFNEY V. 2007. A geomorphological investigation of submerged depositional features within the Outer Silver Pit, southern North Sea. In V. Gaffney, K. Thomson, S. Fitch (eds.), Mapping Dogger- land: the Mesolithic Landscapes of the Southern North Sea. Archaeopress. Oxford: 43-59.

BRYN P., BERG K., FORSBERG C. F., SOLHEIM A., KVALSTAD T. J. 2005. Explaining the Storegga Slide. Marine and Petroleum. Geology 22: 11-19.

BUNGENSTOCK F. 2006. Der holozäne Meeresspiegelanstieg südlich der ostfriesischen Insel Langeoog, südliche Nordsee - hochfrequente Meeresspiegelbewegungen während der letzten 6000 Jahre. PhD-Thesis. MathematischNaturwissenschaftliche Fakultät der Rheinischen FriedrichWilhelms-Universität Bonn. Available online: http://hss. ulb.uni-bonn.de/diss_online

COLES B. J. 1998. 'Doggerland': a speculative survey. Proc. Prehist. Society 64: 45-81.

COLES B. 1999. Doggerland's loss and the Neolithic. In B. Coles, J. Coles, M. Schou Jorgensen (eds.), Bog Bodies, Sacred Sites and Wetland Archaeology. WARP (Wetland Archaeology Research Project) Occasional Paper 12. Department of Archaeology, University of Exeter. Exeter: 51-57.

CONRADSEN K., HEIER-NIELSEN S. 1995. Holocene paleoceanography and paleoenvironments of the SkagerrakKattegatt, Scandinavia. Paleoceanography 10: 810-813.

CONSTANDSE-WESTERMANN T. S., NEWELL R. R. 1989. Social and biological aspects of the Western European Mesolithic population structure: a comparison with the demography of North American Indians. In C. Bonsall (ed.), The Mesolithic in Europe. Edinburgh University Press. Edinburgh: 106-115.

DAWSON S., SMITH D. E. 1997. Holocene relative sea-level changes on the margin of a glacio-isostatically uplifted area: an example from northern Caithness, Scotland. The Holocene 7 (1): 59-77.

DAWSON A. G., LONG D., SMITH D. E. 1988: The Storegga Slides: evidence from eastern Scotland for a possible tsunami. Marine Geology 82: 271-276.

DAWSON A. G., SMITH D. E., LONG D. 1990. Evidence for a tsunami from a Mesolithic site in Inverness, Scotland. Journal of Archaeological Science 17 (6): 509-512.

DAWSON A. G., LONG D., SMITH D. E., SHI S., FOSTER I. D. L. 1993. Tsunamis in the Norwegian Sea and North Sea caused by the Storegga submarine landslides. In S. Tinti (ed.), Tsunamis in the World. Kluwer Academic Publishers. The Netherlands: 228.

DAWSON A. 2008. The Tsunami Risk Project, on-line: www.nerc-bas.ac.uk/tsunami-risks/html/Phy3Impact. htm. 
DIX J., QUINN R., WESTLEY K. 2008. A Re-assessment of the Archaeological Potential of Continental Shelves. Final Report. Department of Archaeology, University of Southampton, available on-line: http://www.arch.soton.ac.uk/ Research/Aggregates/shelve-report.htm.

DONOVAN D. T. 1975. The geology and origin of the Silver Pit and other closed basins in the North Sea. Proceedings of the Yorkshire Geological Society 39: 267-293.

EDINBOROUGH K. 2004. Evolution of Bow Arrow Technology. Unpubl. PhD thesis: University College London.

ERDBRINK D. P. B., TACOMA J. 1997. Une calotte humaine datée au ${ }^{14} \mathrm{C}$ du basin sud de la mer du Nord. L'Anthropolgie 100: 541-545.

FISCHER A. 1997. People and the sea - settlement and fishing along the Mesolithic coast. In L. Pedersen, A. Fischer, B. Aaby (eds.), The Danish Storebolt Since the Ice Age. A/S Storebælt Fixed Link, Kalundborg Museum, National Forest and Nature Agency and the National Museum of Denmark. Copenhagen: 63-77.

2004. Submerged Stone Age - Danish examples and North Sea potential. In N. C. Flemming (ed.), Submarine prehistoric archaeology of the North Sea. Council for British Archaeology. York: 23-36.

FITCH S., THOMSON K., GAFFNEY V. 2005. Late Pleistocene and Holocene depositional systems and the palaeogeography of the Dogger Bank, North Sea. Quaternary Research 64: 185-196.

GAFFNEY V., THOMSON K., FITCH S. (eds.) 2007. Mapping Doggerland: the Mesolithic Landscapes of the Southern North Sea. Archaeopress. Oxford.

GILLESPIE R., GOWLETT J. A. J., HALL E. T., HEDGES R. E. M. 1984. Radiocarbon measurements by accelerator mass spectrometry: an early selection of dates. Archaeometry 26: $15-20$.

GLIMMERVEEN J., MOL D., POST K., REUMER J. W. F., van der PLICHT H., van GEEL B., van REENEN G., PALS J. P. 2004. The North Sea project. The first palaeontological, palynological and archaeological results. In N. C. Flemming (ed.), Submarine Prehistoric Archaeology of the North Sea. Council for British Archaeology Research Report 141: 21-36.

GRAUERT M. S., BJÖRCK S., BONDEVIK S. 2001. Storegga tsunami deposits in a coastal lake on Suduroy, the Faroe Islands. Boreas 30: 263-271.

GROOTES P. M., STUIVER M., WHITE J. W. C., JOHNSEN S., JOUZEL J. 1993. Comparison of Oxygen Isotope Records from the GISP2 and GRIP Greenland Ice Core. Nature 366: 552-554.

GYLLENCREUTZ R. 2005a. Holocene and Latest Glacial Paleoceanography in the North-Eastern Skagerrak. Meddelanden från Stockholms Universitets Institution för Geologgi Och Geokemi No. 322. Available on-line: http://www. gyllencreutz.se/references.html

2005b. Late Glacial and Holocene paleoceanography in the Skagerrak from high-resolution grain size records. Palaegeography, Palaeoclimatology, Palaeoecology 222: 344-369.

HAFLIDASON H., LIEN R., SEJRUP H. P., FORSBERG C. F., BRYN P. 2005. The dating and morphometry of the Storegga Slide. Marine and Petroleum Geology: 123-136.

HARBITZ C. B. 1992. Model simulation of tsunamis generated by the Storegga Slides. Marine Geology 105: 1-21.

HUGHEN K., SOUTHON J., LEHMAN S., BERTRAND C., TURNBULL J. 2006. Marine-derived ${ }^{14} \mathrm{C}$ calibration and activity record for the past 50,000 years updated from the Cariaco Basin. Quaternary Science Reviews 25: 32163227. doi:10.1016/j.quascirev.2006.03.014.

JACOBI R. M. 1976. Britain inside and outside Mesolithic Europe. Proceedings of the Prehistoric Society 42: 6784 .

JELGERSMA S. 1979. Sea-level changes in the North Sea basin. In E. Oerle, R. T. E. Shüttenhelm, A. J. Wiggers (eds.), The Quaternary history of the North Sea. Symposia Universitatis Upsaliensis Annum Quingentesimum Celebrantis 2: $233-248$.

JIANG H., BJÖRCK S., KNUDSEN K. L. 1997. A palaeoclimatic and palaeoceanographic record of the last $1100{ }^{14} \mathrm{C}$ years from the Skagerrak-Kattega.

JOHNSEN S. J., DAHL-JENSEN D., GUNDESTRUP N., STEFFENSEN J. P., CLAUSEN H. B., MILLER H., MASSON-DULMEOTTE V., SVEINBJØRNDOTTIR A. E., WHITE J. 2001. Oxygen isotope and palaeotemperature records from six Greenland ice-core stations: Camp Century, Dye-3, GRIP, GISP2, Renland and NorthGRIP. Journal Quaternary Science 16 (4): 299-307.

KLITGAARD-KRISTENSEN D., SEJRUP H. P., HAFLIDASON H., JOHNSEN S., SPURK M. 1998. A regional 8200 cal. yr BP cooling event in northwest Europe, induced by final stages of the Laurentide ice-sheet deglaciation? Journal of Quaternary Science 13 (2): 165-169.

LAMBECK K. 1995. Late Devensian and Holocene shorelines of the British Isles and North Sea from models of 
glacio-hydro-isostatic rebound. Journal of the Geological Society 152: 437-448.

LeGRANDE A. N. 2006. The Climate Imprint on the Oxygen Isotopic Composition of Water: Observations, Proxies, and Coupled Isotopic Model Simulations. Ph.D. thesis. Columbia University.

LEUENBERGER M., LANG C., SCHWANDER J. 1999. Delta ${ }^{15} \mathrm{~N}$ measurements as a calibration tool for the paleothermometer and gas-ice age differences: A case study for the 8200 B.P event on GRIP ice. Journal of Geophysical Research 104 (22): 163-170.

LONG D., SMITH D. E., DAWSON A. G. 1989. A Holocene tsunami deposit in eastern Scotland. Journal of Quaternary Science 4: 61-66.

LOUWE KOOIJMANS L. P. 1971. Mesolithic bone and antler implements from the North Sea and from the Netherlands. Berichten Rijksdienst voor het Oudheidkundig Bodemonderzoek 20-21:27-73.

MOL D., POST K., REUMER J. W. F., van der PLICHT J., de VOS J. 2006. The Eurogeul-first report of the palaeontological, palynological and archaeological investigations of this part of the North Sea. Quaternary International 142143: $178-85$.

MOL D., GLIMMERVEEN J., POST K., van der PLICHT H., van GEEL B. 2008. Kleine encyclopedie van het leven in het Pleistoceen. Mammoeten, neushoorns en andere dieren van de Noordzeebodem. Veen Magazines. Diemen.

NEWELL R. R., CONSTANDSE-WESTERMANN T. S., van der SANDEN W. A. B., van GIJN A. 1990. An inquiry into the ethnic resolution of Mesolithic regional groups. The study of their decorative ornaments in time and space. Brill. Leyden.

NIEKUS M. J. L. Th. 2006. A geographically referenced ${ }^{14} \mathrm{C}$ database for the Mesolithic and the early phase of the Swifterbant culture in the Northern Netherlands. Palaeohistoria 47/48: 41-99.

NORDBERG K. 1991. Oceanography in the Kattegat and Skagerrak over the past 8000 years. Paleoceanography 4: 461-484.

PALUDAN-MÜLLER C. 1978. High Atlantic food gathering in north-western Zealand: ecological conditions and spatial representation. Studies in Scandinavian Prehistory and Early History 1: 120-57.

PEDERSEN L. 1997. They put fences in the sea. In L. Pedersen, A. Fischer, B. Aaby (eds.), The Danish Storebalt Since the Ice Age. Copenhagen: 124-143.
RAEMAEKERS D. C. M., NIEKUS M. J. L. Th. in press. Developments in Dutch Late Mesolithic: landscape, site location, subsistence and the introduction of pottery. In Ph. Crombé, M. van Strydonck, J. Sergant, M. Bats, M. Boudin (eds.), Proceedings of the international congress "Chronology and Evolution in the Mesolithic of NW Europe", Brussels, May 30 till June 1 2007, Cambridge Scholar Publishing.

REIMER P. J., BAILLIE M. G. L., BARD E., BAYLISS A., BECK J. W., BERTRAND C. J. H., BLACKWELL P. G., BUCK C. E., BURR G. S., CUTLER K. B., DAMON R. L., EDWARDS R. L., FAIRBANKS R. G., FRIEDRICH M., GUILDERSON T. P., HOGG A. G., HUGHEN K. A., KROMER B., McCORMAC F. G., MANNING S. W., RAMSEY C. B., REIMER R. W. REMMELE S., SOUTHON J. R., STUIVER M., TALAMO S., TAYLOR F. W., van der PLICHT J., WEYHENMEYER C. E. 2004. IntCal04 Terrestrial radiocarbon age calibration, 26 - 0 ka BP. $R a$ diocarbon 46: 1029-1058.

ROHLING E. J., PÄLICKE H. 2006. Centennial-scale climate cooling with a sudden cold event around 8,200 years ago. Nature 434: 975-979.

ROZOY J.-G. 1978. Les Derniers Chasseurs. L'Épipaléolithique en France et en Belgique. Essai de Synthèse. Bulletin de la Société Archéologique Champenoise. Charleville.

SCHULTING R. J., RICHARDS M. P. 2001. Dating women and becoming farmers: new palaeodietary and AMS data from the Breton Mesolithic cemeteries of Téviec and Hoëdic. Journal of Anthropological Archaeology 20: 314344 .

SCHULTING R. J. in press. Worm's Head, Caldey Island (south Wales, UK) and the question of Mesolithic territories. In S. B. McCartan, R. J. Schulting, G. Warren, P. C. Woodman (eds.), The Proceedings of the $7^{\text {th }}$ Mesolithic in Europe Conference. Oxbow. Oxford.

SHENNAN I., LAMBECK K., FLATHER R., HORTON B., McARTHUR J., INNES J., LLOYD J., RUTHERFORD M., WINGFIELD R. 2000. Modelling western North Sea palaeogeographies and tidal changes during the Holocene. In I. Shennan, J. Andrews (eds), Holocene Land-Ocean Interaction and Environmental Change around the North Sea. Geological Society, London, Special Publications 166: 299-319.

SHI S., SMITH D. E. 2003. Coastal Tsunami geomorphological impacts and sedimentation processes: Case studies of modern and prehistorical events. Lecture held at the International Conference on Estuaries and Coasts November 9-11, 2003, Hangzhou, China. Available online: http:// www.irtces.org/pdf-hekou/021.pdf 
SMITH D. E., CULLINGFORD R. A., HAGGART B. A. 1985. A major coastal flood during the Holocene in eastern Scotland. Eiszeitalter und Gegenwart 35: 109-118.

SMITH D. E., SHI S., CULLINGFORD R., DAWSON A., DAWSON S., FIRTH C., FOSTER I., FRETWELL P., HAGGART B., HOLLOWAY L., LONG D. 2004. The Holocene Storegga Slidse tsunami in the United Kingdom. Quaternary Science Reviews 23: 2291-2311.

SPIKINS P. A. 2007. Mesolithic Europe: glimpses of another world. In G. Bailey, P. A. Spikins (eds.), Mesolithic Europe. Cambridge University Press. Cambridge: 1-17.

SVENDSEN J. L. 1985. Standforskyvning pá Sunnmøre. Bioog litostratigrafske undersokelser pá Gurskøy, Leinøy og Bergsøy. Thesis, University of Bergen, 142 pp. [Cited in Bondevik et al. 1997].

TELLER J. T., LEVINGTON D. W., MANN J. D. 2002. Freshwater outbursts to the oceans from glacial Lake Agassiz and their role in climate change during the last deglaciation. Quaternary Science Reviews 21: 879-887.

TELLER J. T., MURTY T., NIRUPAMA N., CHITTIBABU P., BAIRD W. F. 2005. Possible Tsunami in the Labrador Sea related to the Drainage of Glacial Lake Agassiz $\sim 8400$ years B.P. Science of Tsunami Hazards 23 (3): 3-16.

THOMAS E. R., WOLFF E. W., MULVANEY R., STEFFENSEN J. P., JOHNSEN S. J., ARROWSMITH C., WHITE J. W. C., VAUGHN B., POPP T. 2007. The 8.2 kyr event from Greenland ice cores. Quaternary Science Reviews 26(1-2): 70-81.

UNITED STATES GEOLOGICAL SURVEY 2008. Data from http://edc.usgs.gov/products/elevation/gtopo30/gtopo30. html

VERHART L. 2005. A drowned land. Mesolithic from the North Sea floor. In L. P. Louwe Kooijmans, P. W. van den Broeke, H. Fokkens, A. L. van Gijn (eds.), The Prehistory of the Netherlands. Amsterdam University Press. Amsterdam: 157-160.

VINTHER B. M., CLAUSEN H. B., JOHNSEN S. J., RASMUSSEN S. O., ANDERSEN K. K., BUCHARDT S. L., DAHL-JENSEN D., SEIERSTAD I. K., SIGGAARD-ANDERSEN M.-L., STEFFENSEN J. P., SVENSSON A. M., OLSEN J., HEINEMEIER J. 2006. A synchronized dating of three Greenland ice cores throu- ghout the Holocene. Journal of Geophysical Research. doi:10.1029/2005JD006921.

WADDINGTON C. (ed.) 2007. Mesolithic Settlement in the North Sea Basin: A Case Study from Howick, NorthEast England. Oxbow and English Heritage. Oxford.

WAGNER B., BENNIKE O., KLUG M., CREMER H. 2007. First indication of Storegga tsunami deposits from East Greenland. Journal of Quaternary Science 22 (4): 321-325.

WARD I., PIERS L., LILLIE M. 2006. The dating of Doggerland - post-glacial geochronology of the southern North Sea. Environmental Archaeology 11 (2): 207-218.

WENINGER B. 1986. High-precision calibration of archaeological radiocarbon dates. Acta Interdisciplinaria Archaeol IV: 11-53.

1995. Stratified ${ }^{14} \mathrm{C}$ Dates and Ceramic Chronologies. Case Studies for the Early Bronze Age at Troy (Turkey) and Ezero (Bulgaria). Radiocarbon 37 (2): 443-456.

WENINGER B., JÖRIS O., DANZEGLOCKE U. 2003. Climate Archaeology with Fortran. Fortran Source Volume 19,1. Spring 2003. Lahey Computer Systems Inc.

WENINGER B., JÖRIS O. 2004. Glacial Radiocarbon Calibration. The CalPal Program. In T. Higham, C. Bronk Ramsey, C. Owen (eds.), Radiocarbon and Archaeology. Fourth International Symposium. Oxford, 2002. Oxford University School of Archaeology Monograph 62: 9-15.

WENINGER B., ALRAM-STERN E., BAUER E., CLARE L., DANZEGLOCKE U., JÖRIS O., KUBATZKI C., ROLLEFSON G., TODOROVA H., van ANDEL T. 2006. Climate forcing due to the 8200 cal yr BP event observed at Early Neolithic sites in the eastern Mediterranean. Quaternary International 66: 401-420.

WENINGER B., EDINBOROUGH K., BRADTMÖLLER M., COLLARD M., CROMBÉ P., DANZEGLOCKE U., HOLST D., JÖRIS 0., NIEKUS M., SHENNON S., SCHULTING R. in press. A Radiocarbon Database for the Mesolithic and Early Neolithic in Northwest Europe. In Ph. Crombé, M. Van Strydonck, J. Sergant, M. Bats, M. Boudin (eds.), Proceedings of the international congress "Chronology and Evolution in the Mesolithic of NW Europe", Brussels, May 30 till June 1 2007. Cambridge Scholar Publishing. 


\section{Appendix}

\section{Tab. 8. Radiocarbon dates for the Storegga Slide tsunami}

\section{Age conventions}

In the present paper all ages are given in tree-ring calibrated calendric years [calBP] before present $(0$ calBP $=$ AD 1950). Calibrated ${ }^{14} \mathrm{C}$-ages are obtained using the software CalPal (www.calpal.de), with methods described in Weninger (1986) and procedures described in Weninger and Jöris (2004), using the tree-ring data set INTCAL04 (Reimer et al. 2004). Conventional ${ }^{14} \mathrm{C}$-ages are given on the ${ }^{14} \mathrm{C}$-scale with units [14C-BP]. To avoid misunderstanding, in the text we provide ages on both time scales. An example is: T-11707A: 7020 $\pm 90{ }^{14} \mathrm{C}-\mathrm{BP}(7840 \pm 90 \mathrm{calBP})$ with laboratory code T-11707A. In this case the conventional ${ }^{14} \mathrm{C}$-age is 7020 $\pm 90{ }^{14} \mathrm{C}-\mathrm{BP}$. The corresponding tree-ring calibrated calendric age is $7840 \pm 90$ calBP. A database containing the ${ }^{14} \mathrm{C}$-ages for the Storegga Slide tsunami, as collated from published studies and used here (Tab. 8). Note that this database does not show the tree-ring calibrated ages for individual dates. For the purposes of the present paper, these values are superfluous. The age-calibrated results based on these dates are shown in the graphs and tables.

\section{References: Abbreviations}

(1) Bondevik et al. 1997; (2) Boomer et al. 2007; (3) Wagner et al. 2007; (4) Smith et al. 2004

\section{Position: Abbreviations}

Position e.g. 'Above Tsunami': in relation to Storegga sand deposit, as defined in reference.

$(\mathrm{R})=$ Regressive Contact (defined by Smith et al. 2004).

$(\mathrm{T})=$ Transgressive Contact (defined by Smith et al. 2004).

\begin{tabular}{|c|c|c|c|c|c|c|c|c|c|}
\hline Lab Code & ${ }^{14} \mathrm{C}$-Age & $\begin{array}{l}{ }^{3} \mathrm{C}- \\
\text { PDB }\end{array}$ & Material & Country & Site & Position & Latitude & Long. & Reference \\
\hline Tua-522 & $7080 \pm 80$ & $-26,1$ & Twig & Norway & Almesstadmyra & above Tsunami & 62,2175 & 5,6675 & (1) \\
\hline $\mathrm{T}-11707 \mathrm{~A}$ & $7020 \pm 90$ & $-29,6$ & Gyttja & Norway & Auretjorn & above Tsunami & 60,9564 & 4,8147 & (1) \\
\hline$T-11606 \mathrm{~A}$ & $7320 \pm 140$ & $-29,8$ & Gyttja & Norway & Auretjorn & above Tsunami & 60,9564 & 4,8147 & (1) \\
\hline T-10599A & $6865 \pm 105$ & $-30,7$ & Gyttja & Norway & Endrevatnet & above Tsunami & 62,4331 & 6,2708 & (1) \\
\hline $\mathrm{T}-10598 \mathrm{~A}$ & $7105 \pm 135$ & $-30,6$ & Gyttja & Norway & Endrevatnet & above Tsunami & 62,4331 & 6,2708 & (1) \\
\hline$T-4162$ & $7490 \pm 90$ & $-32,1$ & Gyttja & Norway & Endrevatnet & above Tsunami & 62,4331 & 6,2708 & (1) \\
\hline $\mathrm{T}-10592 \mathrm{~A}$ & $7500 \pm 80$ & $-25,2$ & Gyttja & Norway & Froystadmyra & above Tsunami & 62,3253 & 5,6764 & (1) \\
\hline $\mathrm{T}-10593 \mathrm{~A}$ & $7615 \pm 150$ & -26 & Gyttja & Norway & Froystadmyra & above Tsunami & 62,3253 & 5,6764 & $(1)$ \\
\hline $\mathrm{T}-11708 \mathrm{~A}$ & $7475 \pm 110$ & $-29,9$ & Gyttja & Norway & Forlandsvatnet & above Tsunami & 60,8906 & 4,8442 & (1) \\
\hline $\mathrm{T}-11249 \mathrm{~A}$ & $7605 \pm 105$ & $-29,8$ & Gyttja & Norway & Gorrtjonna I & above Tsunami & 63,8264 & 9,8308 & (1) \\
\hline $\mathrm{T}-11244 \mathrm{~A}$ & $7100 \pm 125$ & $-29,8$ & Gyttja & Norway & Kvennavatnet & above Tsunami & 63,8347 & 9,8225 & $(1)$ \\
\hline $\mathrm{T}-12013 \mathrm{~A}$ & $7570 \pm 90$ & -30 & Gyttja & Norway & Kvennavatnet & above Tsunami & 63,8347 & 9,8225 & (1) \\
\hline $\mathrm{T}-10595 \mathrm{~A}$ & $6550 \pm 100$ & $-29,9$ & Gyttja & Norway & Ratvikvatnet & above Tsunami & 62,4619 & 6,2242 & (1) \\
\hline $\mathrm{T}-10594 \mathrm{~A}$ & $7430 \pm 95$ & $-29,5$ & Gyttja & Norway & Ratvikvatnet & above Tsunami & 62,4619 & 6,2242 & (1) \\
\hline $\mathrm{T}-10590 \mathrm{~A}$ & $7130 \pm 95$ & $-30,6$ & Gyttja & Norway & Skolemyra & above Tsunami & 62,3331 & 5,6486 & (1) \\
\hline $\mathrm{T}-10591 \mathrm{~A}$ & $7205 \pm 90$ & $-30,2$ & Gyttja & Norway & Skolemyra & above Tsunami & 62,3331 & 5,6486 & (1) \\
\hline $\mathrm{T}-11278 \mathrm{~A}$ & $6575 \pm 110$ & $-30,4$ & Gyttja & Norway & Skolemyra & above Tsunami & 62,3331 & 5,6486 & (1) \\
\hline $\mathrm{T}-11277 \mathrm{~A}$ & $6890 \pm 65$ & $-30,7$ & Gyttja & Norway & Skolemyra & above Tsunami & 62,3331 & 5,6486 & (1) \\
\hline $\mathrm{T}-11276 \mathrm{~A}$ & $7045 \pm 70$ & $-30,1$ & Gyttja & Norway & Skolemyra & above Tsunami & 62,3331 & 5,6486 & (1) \\
\hline $\mathrm{T}-11245 \mathrm{~A}$ & $7610 \pm 100$ & $-29,4$ & Gyttja & Norway & Skolemyra & above Tsunami & 62,3331 & 5,6486 & (1) \\
\hline Tua-862A & $7850 \pm 85$ & $-27,7$ & Gyttja & Norway & Skolemyra & above Tsunami & 62,3331 & 5,6486 & (1) \\
\hline$T-11282 \mathrm{~A}$ & $5695 \pm 100$ & $-30,6$ & Gyttja & Norway & Asetjorn & above Tsunami & 60,9056 & 4,8797 & (1) \\
\hline$T-11281 \mathrm{~A}$ & $6406 \pm 85$ & $-30,2$ & Gyttja & Norway & Asetjorn & above Tsunami & 60,9056 & 4,8797 & (1) \\
\hline $\mathrm{T}-1128 \mathrm{OA}$ & $6995 \pm 110$ & $-30,7$ & Gyttja & Norway & Asetjorn & above Tsunami & 60,9056 & 4,8797 & (1) \\
\hline
\end{tabular}


The catastrophic final flooding of Doggerland by the Storegga Slide tsunami

\begin{tabular}{|c|c|c|c|c|c|c|c|c|c|}
\hline Lab Code & ${ }^{14} \mathrm{C}$-Age & $\begin{array}{c}{ }^{13} \mathrm{C}- \\
\mathrm{PDB}\end{array}$ & Material & Country & Site & Position & Latitude & Long. & Reference \\
\hline $\mathrm{T}-12260 \mathrm{~A}$ & $7180 \pm 95$ & $-30,8$ & Gyttja & Norway & Asetjorn & above Tsunami & 60,9056 & 4,8797 & (1) \\
\hline $\mathrm{T}-112 \mathrm{O} 2 \mathrm{~A}$ & $7230 \pm 105$ & $-31,1$ & Gyttja & Norway & Asetjorn & above Tsunami & 60,9056 & 4,8797 & (1) \\
\hline Tua-1350 & $7315 \pm 70$ & $-22,9$ & Moss & Norway & Audalsvatnet & within Tsunami & 63,8314 & 9,8289 & (1) \\
\hline $\mathrm{T}-11705 \mathrm{~A}$ & $8090 \pm 120$ & $-28,5$ & Detritus & Norway & Auretjorn & within Tsunami & 60,9564 & 4,8147 & (1) \\
\hline Tua-523 & $7655 \pm 85$ & $-26,1$ & Twig & Norway & Froystadmyra & within Tsunami & 62,3253 & 5,6764 & (1) \\
\hline$\overline{T-11246 \mathrm{~A}}$ & $7985 \pm 115$ & $-24,8$ & Detritus & Norway & Froystadmyra & within Tsunami & 62,3253 & 5,6764 & (1) \\
\hline $\mathrm{T}-4967 \mathrm{~A}$ & $8480 \pm 160$ & $-27,8$ & Detritus & Norway & Froystadmyra & within Tsunami & 62,3253 & 5,6764 & (1) \\
\hline $\mathrm{T}-11710 \mathrm{~A}$ & $8040 \pm 160$ & $-30,5$ & Detritus & Norway & Forlandsvatnet & within Tsunami & 60,8906 & 4,8442 & (1) \\
\hline Tua-834 & $6970 \pm 175$ & -26 & Twig & Norway & Gorrtjonna I & within Tsunami & 63,8264 & 9,8308 & (1) \\
\hline Tua-835 & $7930 \pm 65$ & $-26,1$ & Twig & Norway & Gorrtjonna I & within Tsunami & 63,8264 & 9,8308 & (1) \\
\hline Tua-1269 & $7445 \pm 65$ & $-29,5$ & Twig & Norway & Gorrtjonna I & within Tsunami & 63,8264 & 9,8308 & (1) \\
\hline Tua-1122 & $7175 \pm 75$ & $-30,7$ & Twig & Norway & Klingrevatnet & within Tsunami & 62,4424 & 6,2324 & (1) \\
\hline Tua-833 & $8285 \pm 185$ & $-27,7$ & Calluna & Norway & Kulturmyra & within Tsunami & 62,3319 & 5,6553 & (1) \\
\hline TUa-831 & $7240 \pm 70$ & $-27,7$ & Twig & Norway & Kvennavatnet & within Tsunami & 63,8347 & 9,8225 & (1) \\
\hline TUA-984 & $7200 \pm 80$ & $-26,1$ & twig & Norway & Kvennavatnet & within Tsunami & 63,8347 & 9,8225 & (1) \\
\hline TUa-832 & $8405 \pm 70$ & 1 & Shell & Norway & Kvennavatnet & within Tsunami & 63,8347 & 9,8225 & (1) \\
\hline TUa-859 & $10780 \pm 95$ & 1 & Shell & Norway & Kvennavatnet & within Tsunami & 63,8347 & 9,8225 & (1) \\
\hline$T-10597$ & $7230 \pm 105$ & $-26,1$ & Twig & Norway & Ratvikvatnet & within Tsunami & 62,4619 & 6,2242 & (1) \\
\hline$T-10596$ & $7610 \pm 70$ & $-26,1$ & Wood & Norway & Ratvikvatnet & within Tsunami & 62,4619 & 6,2242 & (1) \\
\hline TUa-861 & $7250 \pm 75$ & $-26,1$ & Bark & Norway & Skolemyra & within Tsunami & 62,3331 & 5,6486 & (1) \\
\hline TUa-524 & $7365 \pm 90$ & $-26,1$ & Twig & Norway & Skolemyra & within Tsunami & 62,3331 & 5,6486 & (1) \\
\hline TUa-86o & $7435 \pm 75$ & $-26,1$ & Bark & Norway & Skolemyra & within Tsunami & 62,3331 & 5,6486 & (1) \\
\hline $\mathrm{T}-11275 \mathrm{~A}$ & $8315 \pm 110$ & $-24,9$ & Detritus & Norway & Skolemyra & within Tsunami & 62,3331 & 5,6486 & (1) \\
\hline TUa-858 & $7765 \pm 80$ & $-26,1$ & Twig & Norway & Skolemyra & within Tsunami & 62,3331 & 5,6486 & (1) \\
\hline $\mathrm{T}-11279 \mathrm{~A}$ & $7915 \pm 70$ & $-30,4$ & Detritus & Norway & Asetjorn & within Tsunami & 60,9056 & 4,8797 & (1) \\
\hline TUa-864 & $8045 \pm 75$ & $-26,1$ & Twig & Norway & Asetjorn & within Tsunami & 60,9056 & 4,8797 & (1) \\
\hline TUa-863 & $8350 \pm 80$ & $-26,1$ & Twig & Norway & Asetjorn & within Tsunami & 60,9056 & 4,8797 & (1) \\
\hline $\mathrm{T}-11704 \mathrm{~A}$ & $7320 \pm 80$ & $-29,9$ & Gyttja & Norway & Auretjorn & directly below & 60,9564 & 4,8147 & (1) \\
\hline $\mathrm{T}-11247 \mathrm{~A}$ & $9020 \pm 155$ & $-26,1$ & Gyttja & Norway & Froystadmyra & directly below & 62,3253 & 5,6764 & (1) \\
\hline $\mathrm{T}-11709 \mathrm{~A}$ & $7985 \pm 150$ & $-29,5$ & Gyttja & Norway & Forlandsvatnet & directly below & 60,8906 & 4,8442 & (1) \\
\hline $\mathrm{T}-11250 \mathrm{~A}$ & $7680 \pm 70$ & $-32,5$ & Gyttja & Norway & Gorrtjonna I & directly below & 63,8264 & 9,8308 & (1) \\
\hline $\mathrm{T}-11837 \mathrm{~A}$ & $8340 \pm 115$ & $-29,7$ & Gyttja & Norway & Kulturmyra & directly below & 62,3319 & 5,6553 & (1) \\
\hline TUa-1270 & $7350 \pm 80$ & $-22,3$ & Moss & Norway & Kvennavatnet & directly below & 63,8347 & 9,8225 & (1) \\
\hline $\mathrm{T}-11201 \mathrm{~A}$ & $7805 \pm 115$ & $-29,6$ & Gyttja & Norway & Asetjorn & directly below & 60,9056 & 4,8797 & (1) \\
\hline Oxa-11833 & $7269 \pm 39$ & $-24,9$ & Hazelnut & England & Howick & directly above & 55,4403 & $-1,5917$ & (2) \\
\hline Oxa-11858 & $7308 \pm 40$ & $-25,6$ & Hazelnut & England & Howick & directly above & 55,4403 & $-1,5917$ & $(2)$ \\
\hline OxA-11860 & $7160 \pm 40$ & $-27,3$ & Twig & England & Howick & above Tsunami & 55,4403 & $-1,5917$ & (2) \\
\hline OxA-11859 & $7174 \pm 35$ & $-26,4$ & Wood & England & Howick & above Tsunami & 55,4403 & $-1,5917$ & $(2)$ \\
\hline OxA-12954 & $7075 \pm 37$ & $-30,7$ & Bark & England & Howick & above Tsunami & 55,4403 & $-1,5917$ & (2) \\
\hline OxA-12953 & $7117 \pm 39$ & $-26,1$ & Hazelnut & England & Howick & above Tsunami & 55,4403 & \begin{tabular}{|l|}
$-1,5917$ \\
\end{tabular} & (2) \\
\hline OxA-12952 & $6988 \pm 37$ & $-26,5$ & Hazelnut & England & Howick & above Tsunami & 55,4403 & $-1,5917$ & $(2)$ \\
\hline KIA-24754 & $6735 \pm 40$ & 0,41 & Shell & Greenland & Loon Lake & above Tsunami & 72,8839 & $-22,1342$ & (3) \\
\hline $\mathrm{KIA}-27660$ & $7720 \pm 45$ & $-0,77$ & Shell & Greenland & Loon Lake & above Tsunami & 72,8839 & $-22,1342$ & (3) \\
\hline KIA-27661 & $7925 \pm 45$ & 0,85 & Shell & Greenland & Loon Lake & directly above & 72,8839 & $-22,1342$ & (3) \\
\hline KIA-27662 & $7640 \pm 45$ & 1,68 & Shell & Greenland & Loon Lake & within Tsunami & 72,8839 & $-22,1342$ & (3) \\
\hline $\mathrm{KIA}-27663$ & $7515 \pm 45$ & 1,54 & Shell & Greenland & Loon Lake & directly below & 72,8839 & $-22,1342$ & (3) \\
\hline KIA-27664 & $7820 \pm 45$ & 0,37 & Shell & Greenland & Loon Lake & under Tsunami & 72,8839 & $-22,1342$ & (3) \\
\hline $\mathrm{KIA}-27665$ & $7555 \pm 45$ & 0,56 & Shell & Greenland & Loon Lake & under Tsunami & 72,8839 & $-22,1342$ & (3) \\
\hline KIA-24755 & $7625 \pm 60$ & $-5,95$ & Shell & Greenland & Loon Lake & under Tsunami & 72,8839 & $-22,1342$ & (3) \\
\hline SRR 4902 & $7215 \pm 60$ & -27.4 & Peat & Shetland & Burragarth & $R$ & 60,7134 & $-0,949$ & (4) \\
\hline
\end{tabular}




\begin{tabular}{|c|c|c|c|c|c|c|c|c|c|}
\hline Lab Code & ${ }^{14}$ C-Age & $\begin{array}{l}{ }^{13} \mathrm{C}- \\
\text { PDB }\end{array}$ & Material & Country & Site & Position & Latitude & Long. & Reference \\
\hline Beta169274 & $6840 \pm 40$ & -25.0 & Peat & Shetland & Norwick & $R$ & 60,807 & $-0,8196$ & (4) \\
\hline SRR 1793 & $5130 \pm 50$ & n.d & Wood & Shetland & Garth's Voe & above Tsunami & 60,4371 & $-1,2746$ & (4) \\
\hline SRR 1794 & $7870 \pm 50$ & n.d & Wood & Shetland & Garth's Voe & below Tsunami & 60,4371 & $-1,2746$ & (4) \\
\hline SRR 3839 & $5315 \pm 45$ & -28.8 & Peat & Shetland & Garth's Voe & $R$ & 60,4371 & $-1,2746$ & (4) \\
\hline SRR 3838 & $5765 \pm 45$ & -27.8 & Peat & Shetland & Garth's Voe & $T$ & 60,4371 & $-1,2746$ & (4) \\
\hline SRR 3841 & $3815 \pm 45$ & -28.5 & Peat & Shetland & Scatsta Voe & $R$ & 60,4367 & $-1,275$ & (4) \\
\hline SRR 3840 & $5700 \pm 45$ & -28.5 & Peat & Shetland & Scatsta Voe & $T$ & 60,4367 & $-1,275$ & (4) \\
\hline n.d & $7025 \pm 60$ & n.d. & Wood & Shetland & Sullom Voe & $\mathrm{R}$ & 60,5132 & $-1,3641$ & (4) \\
\hline n.d. & $7120 \pm 60$ & n.d. & Seeds & Shetland & Sullom Voe & $T$ & 60,5132 & $-1,3641$ & (4) \\
\hline n.d. & $7320 \pm 70$ & n.d, & Twig & Shetland & Garth Loch & within Tsunami & 60,2647 & $-1,1536$ & (4) \\
\hline n.d. & $7220 \pm 70$ & n.d. & Seeds, Leave & sShetland & Garth Loch & directly above & 60,2647 & $-1,1536$ & (4) \\
\hline Beta105030 & $7290 \pm 50$ & -31.4 & Peat & Scotland & Strath Halladale & $R$ & 58,5375 & $-3,9062$ & (4) \\
\hline Beta105031 & $7590 \pm 50$ & -30.5 & Peat & Scotland & Strath Halladale & $\mathrm{T}$ & 58,5375 & $-3,9062$ & (4) \\
\hline Beta 89710 & $7070 \pm 80$ & -27.9 & Peat & Scotland & Wick River & $\mathrm{R}$ & 58,4533 & $-3,1283$ & (4) \\
\hline Beta 89709 & $7210 \pm 80$ & -27.6 & Peat & Scotland & Wick River & $T$ & 58,4533 & $-3,1283$ & (4) \\
\hline Beta89706 & $7170 \pm 80$ & -28.4 & Peat & Scotland & Wick River & $\mathrm{R}$ & 58,4533 & $-3,1283$ & (4) \\
\hline Beta89707 & $7140 \pm 90$ & -29.4 & Peat & Scotland & Wick River & $T$ & 58,4533 & $-3,1283$ & (4) \\
\hline Beta89712 & $7810 \pm 70$ & -28.4 & Peat & Scotland & Wick River & $T$ & 58,4533 & $-3,1283$ & (4) \\
\hline SRR 3791 & $6580 \pm 55$ & -29.0 & Peat & Scotland & Smithy House & $\mathrm{R}$ & 57,9654 & $-4,0095$ & (4) \\
\hline SRR 3792 & $6980 \pm 65$ & -29.0 & Peat & Scotland & Smithy House & $\mathrm{R}$ & 57,9654 & $-4,0095$ & (4) \\
\hline SRR 3694 & $6930 \pm 55$ & -27.6 & Peat & Scotland & Creich & $\mathrm{R}$ & 57,8682 & $-4,2781$ & (4) \\
\hline SRR 3693 & $6950 \pm 55$ & -28.9 & Peat & Scotland & Creich & $T$ & 57,8682 & $-4,2781$ & (4) \\
\hline SRR 3787 & $5190 \pm 65$ & -27.5 & Peat & Scotland & Dounie & $\mathrm{R}$ & 57,8456 & $-4,1971$ & (4) \\
\hline SRR 3790 & $7120 \pm 45$ & -27.7 & Peat & Scotland & Dounie & $T$ & 57,8456 & $-4,1971$ & (4) \\
\hline BIRM 1126 & $7270 \pm 90$ & -21.6 & Peat & Scotland & Moniack & $R$ & 57,463 & $-4,4312$ & (4) \\
\hline BIRM 1127 & $7430 \pm 170$ & -21.1 & Peat & Scotland & Moniack & $T$ & 57,463 & $-4,4312$ & (4) \\
\hline GU 1377 & $7080 \pm 85$ & -25.5 & Charcoal & Scotland & Castle St.Inverness & $T$ & 57,6754 & $-4,5994$ & (4) \\
\hline SRR 5478 & $6905 \pm 55$ & -27.3 & Peat & Scotland & Water of Philorth & $\mathrm{R}$ & 57,6672 & $-1,976$ & (4) \\
\hline SRR 5479 & $7395 \pm 45$ & -29.2 & Peat & Scotland & Water of Philorth & $\mathrm{T}$ & 57,6672 & $-1,976$ & (4) \\
\hline SRR 5473 & $6995 \pm 45$ & -28.1 & Peat & Scotland & Water of Philorth & $\mathrm{R}$ & 57,6672 & $-1,976$ & (4) \\
\hline SRR 5474 & $7215 \pm 45$ & -28.9 & Peat & Scotland & Water of Philorth & $T$ & 57,6672 & $-1,976$ & (4) \\
\hline SRR 1565 & $6850 \pm 140$ & -26.0 & Peat & Scotland & Waterside & RžT & 57,3284 & $-1,9904$ & (4) \\
\hline SRR 4717 & $7135 \pm 45$ & -28.1 & Peat & Scotland & Tarty Burn & $\mathrm{R}$ & 57,3342 & $-2,0292$ & (4) \\
\hline SRR 4718 & $7400 \pm 45$ & -28.4 & Peat & Scotland & Tarty Burn & $T$ & 57,3342 & $-2,0292$ & (4) \\
\hline SRR 2119 & $6850 \pm 75$ & -28.8 & Peat & Scotland & Puggieston & $R$ & 56,7315 & $-2,493$ & (4) \\
\hline SRR 2120 & $7120 \pm 75$ & -27.4 & Peat & Scotland & Puggieston & $T$ & 56,7315 & $-2,493$ & (4) \\
\hline BIRM 867 & $6880 \pm 110$ & -26.8 & Peat & Scotland & Fullerton & $\mathrm{R}$ & 56,694 & $-2,5319$ & (4) \\
\hline BIRM 823 & $7140 \pm 120$ & -26.8 & Peat & Scotland & Fullerton & $T$ & 56,694 & $-2,5319$ & (4) \\
\hline Beta92235 & $7070 \pm 130$ & -28.9 & Peat & Scotland & Maryton & $R$ & 56,6993 & $-2,5166$ & (4) \\
\hline Beta92236 & $7420 \pm 120$ & -28.8 & Peat & Scotland & Maryton & $T$ & 56,6993 & $-2,5166$ & (4) \\
\hline n.d. & $7605 \pm 130$ & n.d. & Peat & Scotland & Silver Moss & $T$ & 56,4905 & $-2,8852$ & (4) \\
\hline SRR 1333 & $7050 \pm 100$ & -28.1 & Peat & Scotland & Silver Moss & $\mathrm{R}$ & 56,4905 & $-2,8852$ & (4) \\
\hline SRR 1334 & $7555 \pm 110$ & -23.6 & Peat & Scotland & Silver Moss & $T$ & 56,4905 & $-2,8852$ & (4) \\
\hline SRR 1603 & $6870 \pm 50$ & -26.6 & Peat & \multicolumn{2}{|c|}{ ScotlandOver Easter Offerance } & $T$ & 56,1375 & $-4,2909$ & (4) \\
\hline SRR 1431 & $7490 \pm 70$ & -28.1 & Gyttja & Scotland & Lochhouses & $\mathrm{R}$ & 56,0305 & $-2,6167$ & (4) \\
\hline SRR 1430 & $7450 \pm 60$ & -29.1 & Gyttja & Scotland & Lochhouses & $\mathrm{T}$ & 56,0305 & $-2,6167$ & (4) \\
\hline SRR 3912 & $7315 \pm 70$ & -30.0 & Gyttja & Scotland & Lochhouses & $\mathrm{R}$ & 56,0305 & $-2,6167$ & (4) \\
\hline SRR 3913 & $7590 \pm 60$ & -30.0 & Gyttja & Scotland & Lochhouses & $T$ & 56,0305 & $-2,6167$ & (4) \\
\hline AA 25596 & $6700 \pm 60$ & -28.2 & Peat & \multicolumn{2}{|c|}{ Scotland Broomhouse Farm } & $R$ & 55,6992 & $-1,9395$ & (4) \\
\hline AA 25601 & $7165 \pm 60$ & -29.0 & Peat & \multicolumn{2}{|c|}{ Scotland Broomhouse Farm } & $\mathrm{T}$ & 55,6992 & $-1,9395$ & (4) \\
\hline
\end{tabular}

